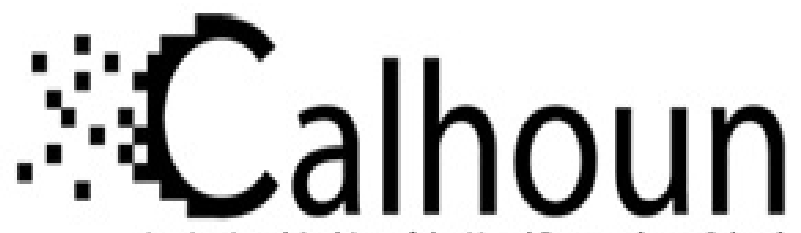

Institutional Archive of the Naval Postgraduate School

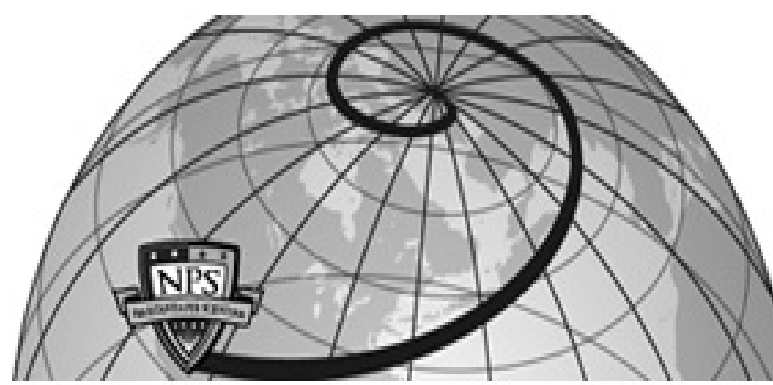

Calhoun: The NPS Institutional Archive

DSpace Repository

Japan/East Sea (JES) circulation and

thermohaline structure, Part 1, Climatology

Lan, Jian; Fan, Chenwu; Chu, Peter C.

Chu, P.C., J. Lan, and C.W. Fan, 2001: Japan/East Sea (JES) circulation and thermohaline structure, Part 1, Climatology (paper download). Journal of Physical Oceanography, American Meteorological Society, 31, 244-271.

http://hdl.handle.net/10945/36126

This publication is a work of the U.S. Government as defined in Title 17, United States Code, Section 101. Copyright protection is not available for this work in the United States.

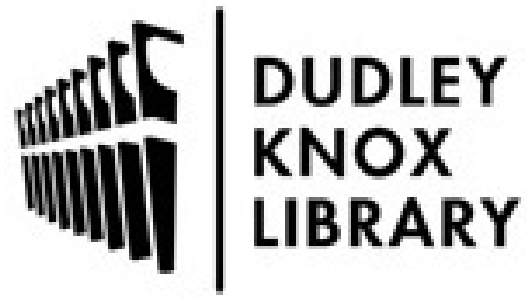

http://www.nps.edu/library
Calhoun is the Naval Postgraduate School's public access digital repository for research materials and institutional publications created by the NPS community. Calhoun is named for Professor of Mathematics Guy K. Calhoun, NPS's first appointed -- and published -- scholarly author.

\section{Dudley Knox Library / Naval Postgraduate School} 411 Dyer Road / 1 University Circle Monterey, California USA 93943 


\title{
Japan Sea Thermohaline Structure and Circulation. Part I: Climatology
}

\author{
Peter C. Chu, Jian Lan, and Chenwu Fan \\ Department of Oceanography, Naval Postgraduate School, Monterey, California
}

(Manuscript received 17 August 1999, in final form 9 April 2000)

\begin{abstract}
In this study, the U.S. Navy's Generalized Digital Environmental Model (GDEM) climatological temperature and salinity data on a $0.5^{\circ} \times 0.5^{\circ}$ grid is used to investigate the seasonal variabilities of the Japan/East Sea (JES) thermohaline structure and circulations. The GDEM for the JES was built up on historical (1930-97) 136509 temperature and 52572 salinity profiles. A three-dimensional estimate of the absolute geostrophic velocity field was obtained from the GDEM temperature and salinity fields using the P-vector method. The seasonal variabilities of the thermohaline structure and the inverted currents such as the Subpolar Front, the salinity minimum and maximum in the Japan Sea Intermediate Water, and the Tsushima Warm Current and its bifurcation are identified.
\end{abstract}

\section{Introduction}

The Japan Sea, known as the East Sea in Korea, has steep bottom topography (Fig. 1) that makes it a unique semienclosed ocean basin overlaid by a pronounced monsoon surface wind. The Japan/East Sea (hereafter JES) covers an area of $10^{6} \mathrm{~km}^{2}$, has a maximum depth in excess of $3700 \mathrm{~m}$, and is isolated from open oceans except for small (narrow and shallow) straits that connect the JES to the Pacific Ocean. The JES contains three major basins called the Japan Basin (JB), Ulleng/ Tsushima Basin (UTB), and Yamato Basin (YB), and a high central seamount called the Yamato Rise. The JES is of great scientific interest as a miniature prototype ocean. Its basinwide circulation pattern, boundary currents, Subpolar Front (SPF), mesoscale eddy activity, and deep-water formation are similar to those in a large ocean.

The JES experiences two monsoons, winter and summer, every year. During the winter monsoon season, a cold northwest wind blows over the JES as a result of the Siberian high pressure system located over the East Asian continent. Radiative cooling and persistent cold air advection maintain cold air over the JES. The northwest-southeast oriented jet stream is positioned above the JES. Such a typical winter monsoon pattern lasts nearly six months (Nov-Apr). During the summer monsoon, a warm and weaker southeast wind blows over the JES. Such a typical summer monsoon pattern lasts nearly 4 months (mid-May to mid-Sep).

Corresponding author address: Dr. Peter C. Chu, Department of Oceanography, Naval Postgraduate School, Monterey, CA 93943. E-mail: chu@nps.navy.mil
The JES thermohaline structure and general circulation have been investigated for several decades. The Tsushima Warm Current (TWC), dominating the surface layer, flows in from Tsushima Strait and carries warm water from the south up to $40^{\circ} \mathrm{N}$ where a polar front forms (Seung and Yoon 1995). Most of the nearly homogeneous water in the deep part of the basin is called the Japan Sea Proper Water (Moriyasu 1972) and is of low temperature and low salinity. Above the Proper Water, warm and saline water flows in through Tsushima Strait, transports northeastward, and flows out through the Tsugaru and Soya Strait.

The TWC separates north of $35^{\circ} \mathrm{N}$ into western and eastern channels (Uda 1934; Kawabe 1982a,b; Hase et al. 1999; Senjyu 1999). The flow through the western channel closely follows the Korean coast [called the East Korean Warm Current (EKWC)] until it bifurcates into two branches near $37^{\circ} \mathrm{N}$. The eastern branch follows the SPF to the western coast of Hokkaido Island, and the western branch moves northward and forms a cyclonic eddy at the eastern Korean Bay. The flow through the eastern channel follows the Japanese coast, called the "Nearshore Branch" by Yoon (1982a-c). More accurately, we may call it the Japan Nearshore Branch (JNB). The JNB is usually weaker than the EKWC. The TWC at both channels decreases with depth. The EKWC meets the southward coastal current, the North Korean Cold Current (NKCC), at about $38^{\circ} \mathrm{N}$ with some seasonal meridional migration. After separation from the coast, the EKWC and the NKCC converge and form a strong front (i.e., SPF) that stretches in a west-east direction across the basin. The NKCC makes a cyclonic recirculation gyre in the north but most of the EKWC flows out through the outlets (Uda 1934). The formation 


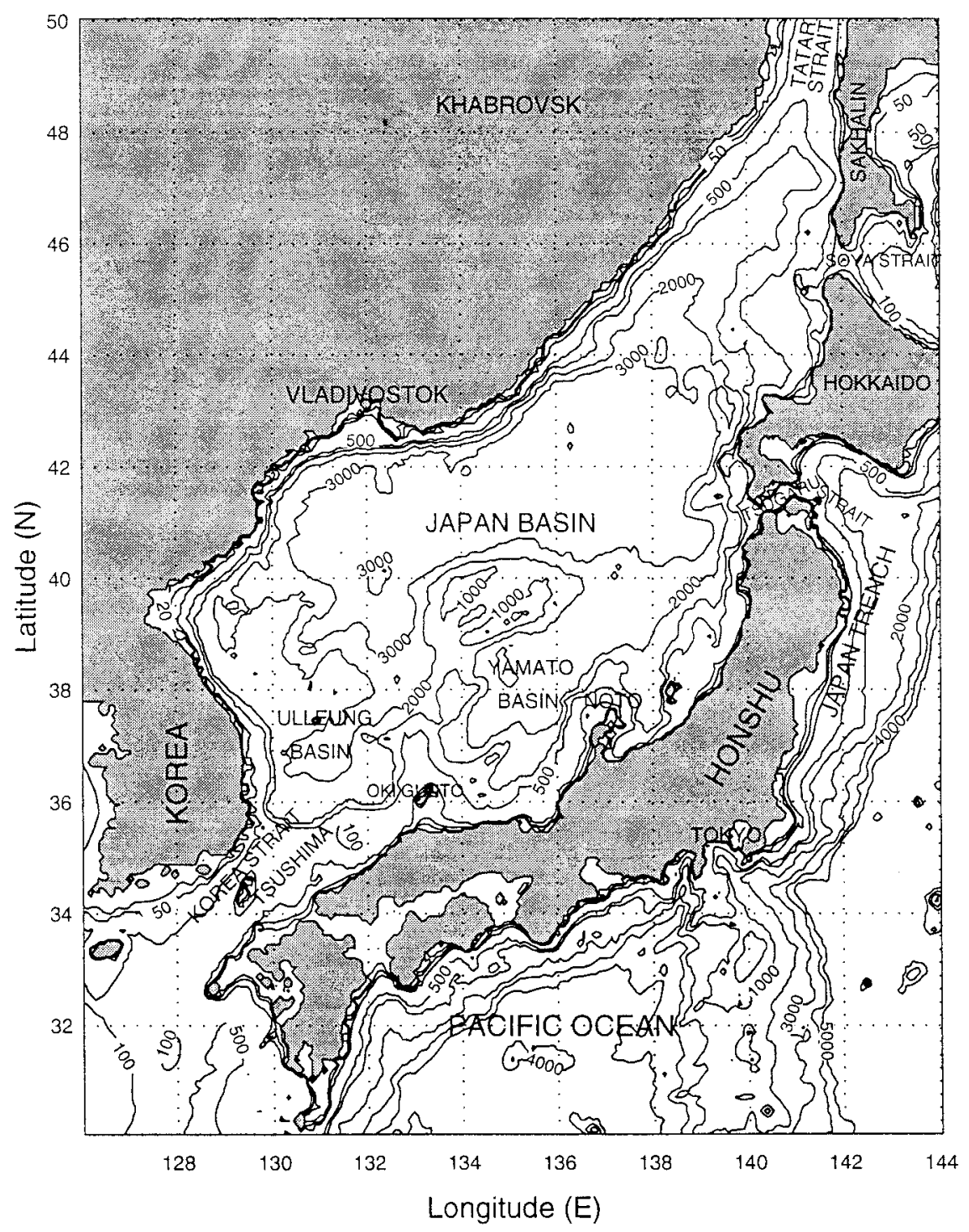

FIG. 1. Geography and isobaths showing the bottom topography (in meters) of the Japan/East Sea (JES).

of the NKCC and the separation of the EKWC are due to a local forcing by wind and buoyancy flux (Seung 1994). Large meanders develop along the front and are associated with warm and cold eddies.

Between the TWC water and the Japan Sea Proper Water, a vertical salinity minimum (SMIN) south of the SPF, usually accompanied by a dissolved oxygen maximum, was first found and named Japan Sea Intermediate Water (JIW) by Miyazaki $(1952,1953)$, and further depicted by Kajiura et al. (1958) and Moriyasu (1972). The collocation of the SMIN and the dissolved oxygen maximum implies that the Intermediate Water originates from the descending surface water around the SPF (Miyazaki 1952, 1953; Miyazaki and Abe 1960). Later, Kim and Chung (1984) found a very similar property in the UTB and proposed the East Sea Intermediate Water (i.e.,
JIW used by Japanese oceanographers); and Kim and Kim (1999) found the high salinity water with high oxygen in the eastern JB (i.e., north of SPF) and named the water "High Salinity Intermediate Water" (HSIW; $>34.07 \mathrm{psu}$ ).

The seasonal variabilities of both the JES circulation and thermohaline structure have been studied based on limited datasets such as the seasonal sea surface temperature (SST) variability (Isoda and Saitoh 1988, 1993; Kano 1980; Maizuru Mar. Observ. 1997). Based on satellite infrared images in the western part of the JES and the routine hydrographic survey by the Korea Fisheries Research and Development Agency in 1987, Isoda and Saitoh (1993) found SST patterns in winter and spring that characterized as follows: a small meander of a thermal front first originated from Tsushima Strait near the 
Korean coast and gradually grew into an isolated warm eddy with a horizontal scale of $100 \mathrm{~km}$. The warm eddy intruded slowly northward from spring to summer. Chu et al. (1998a) reported the seasonal occurrence of JES eddies from the composite analysis on the U.S. National Centers for Environmental Prediction (NCEP) monthly SST fields (1981-94). For example, they identified a warm center appearing in later spring in the East Korean Bay.

What are the seasonal variabilities of the three-dimensional JES circulation and thermohaline structure? We use the U.S. Navy's unclassified Generalized Digital Environmental Model (GDEM) temperature and salinity data on a $0.5^{\circ} \times 0.5^{\circ}$ grid to investigate the problem in this study. The outline of this paper is as follows: A description of the GDEM data is given in section 2. A depiction of the inversion of the absolute geostrophic velocity is given in section 3. Explanations of monthly mean and anomaly fields are given in section 4 . The seasonal variabilities of the three-dimensional thermohaline structure and the inverted velocity field are discussed in sections $5-7$. In section 8 we present our conclusions.

\section{The U.S. Navy's GDEM dataset}

The U.S. Navy's (GDEM) global climatological monthly mean temperature and salinity dataset is a fourdimensional (latitude, longitude, depth, and month) display. Data for building the present version of the GDEM climatology for the JES were obtained from the Navy's Master Oceanographic Observational Data Set (MOODS), which has 136509 temperature and 52572 salinity profiles during 1930-97. The main limitation of the MOODS data is its irregular distribution in time and space. Certain periods and areas are oversampled, while others lack enough observations to gain any meaningful insights. Vertical resolution and data quality are also highly variable depending much on instrument type and sampling expertise (Chu et al. 1997a-d). The monthly distributions of the JES temperature (Fig. 2a) and salinity (Fig. 2b) stations show that the number of temperature stations is two to three times more than the number of salinity stations. January has the least profiles and August the most. Yearly temperature (Fig. 3a) and salinity (Fig. 3b) profile numbers show temporally uneven distribution with almost no observations in the whole JES in certain years (e.g., 1944, 1989 for temperature, and 1944, 1987-93 for salinity) and many observations in other years (e.g., nearly 6500 temperature profiles in 1969, and 3700 salinity profiles in 1967). Spatial and temporal irregularities along with the lack of data in certain regions must be carefully weighted in order to avoid statistically induced variability.

The basic design concept of the GDEM is the determination of a set of analytical curves that represent the mean vertical distributions of temperature and salinity for grid cells $\left(0.5^{\circ} \times 0.5^{\circ}\right)$ through the averaging of coefficients for the curves found for individual profiles (Teague et al. 1990). Different families of representative curves have been chosen for shallow, mid, and deep depth ranges, with each chosen so that the number of parameters required to yield a smooth, mean profile over the range was minimized. As mentioned by Teague et al. (1990), large-scale oceanographic features are generally found to be similarly represented in both the GDEM and the 1982 NOAA Climatological Atlas of the World Ocean temperature and salinity. The GDEM appears to render better representations of seasonal variability and regions of high current shear because of a different smoothing method and a finer grid spacing. The GDEM data contains monthly mean temperature and salinity $(T, S)$ and annual mean temperature and salinity $(\bar{T}, \bar{S})$ fields. Interested readers are referred to Teague et al. (1990) for more information.

\section{The P-vector inverse method}

Recently, we developed the P-vector inverse method (Chu 1995; Chu et al. 1998b,c; Chu 2000; Chu and Li 2000) to calculate the absolute geostrophic velocity. This method contains two steps: (i) determination of the velocity direction and (ii) determination of the velocity magnitude. Two necessary conditions for the inversion are easily implemented into this method: (i) the isopycnal surface does not parallel the potential vorticity surface and (ii) the velocity has a vertical spiral (Chu et al. $1998 b, c)$.

\section{a. Reduced physics}

As pointed out by Wunsch and Grant (1982), in determining large-scale circulation from hydrographic data we can be reasonably confident of the assumptions of geostrophic balance, mass conservation, adiabatic, and no major cross-isopycnal mixing (except for water masses in contact with the atmosphere). Under these conditions, the density of each fluid element would be conserved, which mathematically is given by

$$
\mathbf{V} \cdot \boldsymbol{\nabla} \rho=0,
$$

where $\rho$ is the potential density and $\mathbf{V}=(u, v, w)$ is the geostrophic velocity. The conservation of potential vorticity equation can be obtained by differentiating (1) with respect to $z$, using geostrophic and hydrostatic balances, and including the latitudinal variation of the Coriolis parameter to give

$$
\mathbf{V} \cdot \nabla q=0
$$

where $q=f \partial \rho / \partial z$. Equations (1) and (2) imply that the velocity $\mathbf{V}$ is parallel to $\nabla q \times \nabla \rho$.

\section{b. The P-vector method}

Consider the unit vector $\mathbf{P}$ (Chu 1995) defined by

$$
\mathbf{P}=\frac{\boldsymbol{\nabla} \rho \times \boldsymbol{\nabla} q}{|\boldsymbol{\nabla} \rho \times \boldsymbol{\nabla} q|} .
$$


The existence of this unit vector implies the satisfaction of necessary condition (1).

The velocity, $\mathbf{V}=(u, v, w)$, parallels the unit vector $\mathbf{P}$,

$$
\mathbf{V}=r(x, y, z) \mathbf{P},
$$

where $r$ is the proportionality. Applying the thermal wind relation at two different depths $z_{k}$ and $z_{m}$, a set of algebraic equations for determining the parameter $r$ are obtained

$$
\begin{aligned}
& r^{(k)} P_{x}^{(k)}-r^{(m)} P_{x}^{(m)}=\Delta u_{k m} \\
& r^{(k)} P_{y}^{(k)}-r^{(m)} P_{y}^{(m)}=\Delta v_{k m},
\end{aligned}
$$

which are two linear algebraic equations for $r^{(k)}$ and $r^{(m)}$ $\left[r^{(i)}=r\left(x, y, z_{i}\right)\right]$. Here

$$
\left(\Delta u_{k m}, \Delta v_{k m}\right)=\frac{g}{f \rho_{0}} \int_{z_{m}}^{z_{k}}\left(\frac{\partial \hat{\rho}}{\partial y},-\frac{\partial \hat{\rho}}{\partial x}\right) d z^{\prime},
$$

where $\hat{\rho}$ is the in situ water density, and $\rho_{0}$ is the characteristic value of the density.

The determinant of the coefficient matrix of (5) is the sine of the vertical turning angle between $\mathbf{P}_{h}^{(k)}$ and $\mathbf{P}_{h}^{(m)}$ (Chu et al. 1998b,c; Chu and Li 2000). The existence of solutions of (5) implies the satisfaction of necessary condition (2).

For water columns satisfying the two necessary conditions, we may solve (5) to obtain $r^{(k)}$ for the level $z_{k}$. There are $N-1$ sets $(m=1,2, k-1, k+1, \ldots$, $N$ ) of equations (5) for calculating $r^{(k)}$. Here $N$ is the total number of vertical levels of the water column. All the $N-1$ sets of equations are compatible under the thermal wind constraint and should provide the same solution. However, because of errors in measurements (instrumentation errors) and computations (truncation errors), the parameters $r^{(k)}$ may vary with $m$. A least squares error algorithm is used to minimize the error. For further details and validation of the algorithm presented here see Chu et al. (1998b). (Interested readers can obtain the software by contacting C. Fan at fan@nps.navy.mil or by visiting our Web site at http:/ /www.oc.nps.navy.mil/ chu.)

\section{Monthly mean and anomaly fields}

The GDEM's monthly mean data and inverted velocity field show an evident seasonal variation. The average of the 12 monthly mean fields $(T, S)$ leads to the annual mean field $(\bar{T}, \bar{S})$. The GDEM dataset also provides the annual mean fields. The monthly minus annual mean field is defined as the monthly anomaly field,

$$
T_{\text {an }}=T-\bar{T}, \quad S_{\text {an }}=S-\bar{S},
$$

which represents the seasonal variation relative to the annual mean field.

The seasonal $T, S$ variation reduces as depth increases. At 300-m depth there is almost no seasonal variability. Thus, we present only the horizontal fields at the surface and the intermediate level $(150 \mathrm{~m})$ for illustration. In order to see the seasonal variation of the vertical thermohaline structure, we present the latitudinal and zonal cross sections of the monthly mean fields.

To identify the variability in both monthly mean and monthly mean anomaly fields, we use a cold (warm) center to represent the temperature minimum (maximum), and a fresh (salty) center to represent the salinity minimum (maximum).

\section{Temperature \\ a. Sea surface}

Although the monthly SST field (Fig. 4) shows an evident seasonal variation, the SPF exists continuously throughout the year. Its position is quite stationary, but its intensity strengthens in winter (especially the east part) and weakens in summer. Such a pattern is similar to an earlier description (Maizuru Mar. Observ. 1997). The location of the SPF in spring is quite consistent with Isoda and Saitoh's (1988) estimations using ten NOAA-8 satellite Advanced Very High Resolution Radiometer images in spring 1984.

The SST is found always higher than $5^{\circ} \mathrm{C}$ year-round in the UTB and the YB, consistent with Kim et al.'s (1999) observational studies. The maximum SST gradient is found as $16^{\circ} \mathrm{C} / 100 \mathrm{~km}$ near $137^{\circ} \mathrm{E}, 40^{\circ} \mathrm{N}$ in February and March, and the minimum SST gradient is found as $8^{\circ} \mathrm{C} / 100 \mathrm{~km}$ from July to September. The SST gradient across the SPF is two times as strong in winter as in summer. The weakening of the SPF in summer is caused by the faster warming of the water mass north of rather than south of the SPF in spring. North of the SPF a second front occurs (bifrontal structure) during the fall-to-winter transition season, especially in November and December. This front parallels the Russian coast with the maximum SST gradient around $4^{\circ} \mathrm{C} / 100$ $\mathrm{km}$ in November.

The monthly mean SST anomaly field obtained from the GDEM data (Fig. 5) shows a basin-scale cold anomaly from December to May (winter monsoon) and a basin-scale warm anomaly from June to October (summer monsoon). The strongest basin-scale cooling occurs in February with the coldest anomaly center $\left(T_{\text {an }}<\right.$ $\left.-9^{\circ} \mathrm{C}\right)$ appearing in the central $\mathrm{JB}\left(40^{\circ}-42^{\circ} \mathrm{N}, 135^{\circ}-\right.$ $\left.137.5^{\circ} \mathrm{E}\right)$; and the strongest basin-scale warming occurs in August with the warmest anomaly center $\left(T_{\text {an }}>11^{\circ} \mathrm{C}\right)$ appearing near Peter the Great Bay (PGB).

The typical winter anomaly pattern is featured by (i) all negative values and (ii) eastward expansion of a cold anomaly from the PGB. After the winter monsoon onset, the cold SST anomaly first occurs in the north to northwestern boundary from Tartar Strait to PGB in November with a minimum value around $-1{ }^{\circ} \mathrm{C}$. In December, the cold anomaly sweeps the whole JES basin with the coldest center $\left(-4^{\circ} \mathrm{C}\right)$ at the north to northwestern boundary. The PGB cold center becomes evident with a minimum value of $-6^{\circ} \mathrm{C}$ in January. The PGB cold 

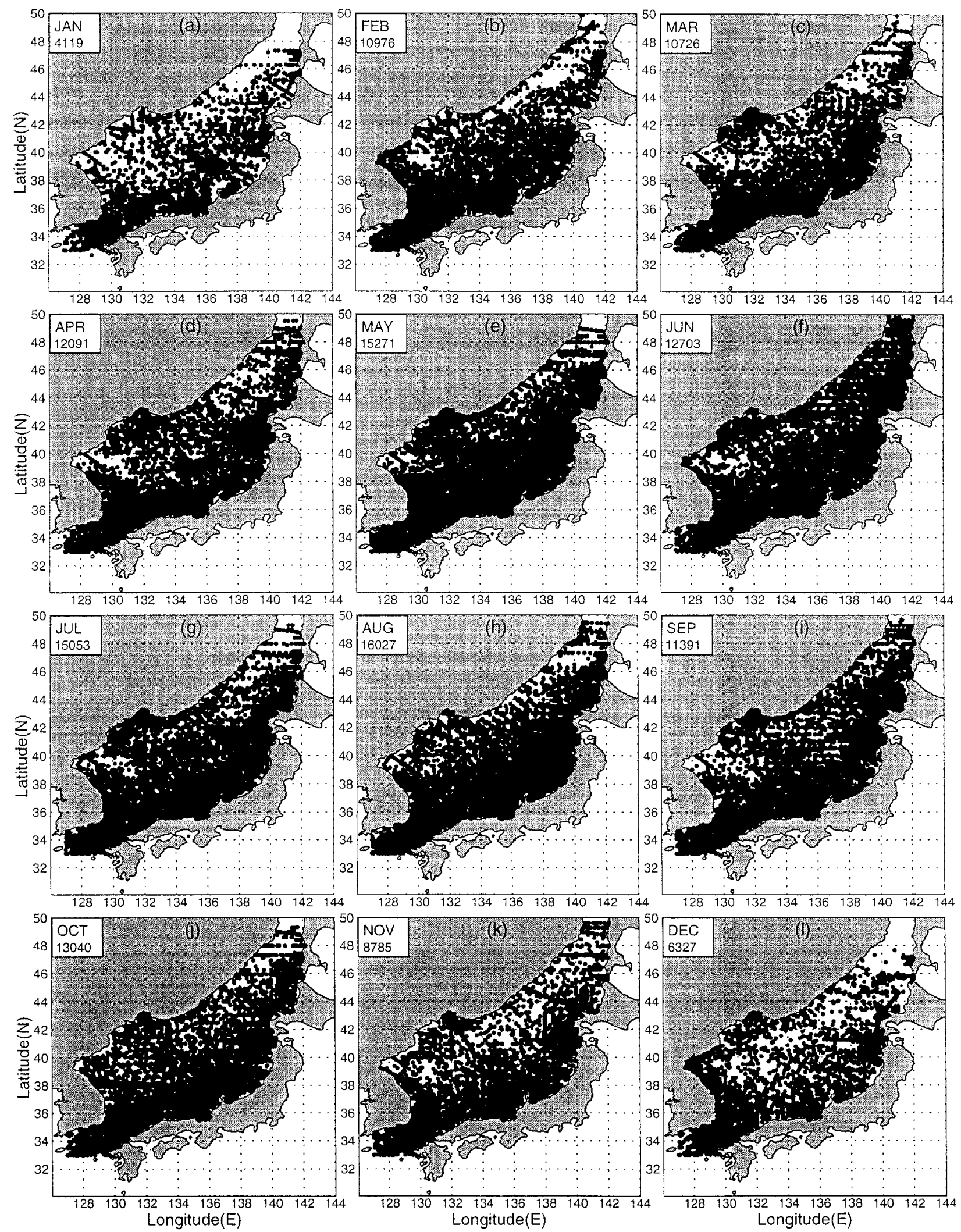

FIG. 2. Spatial distributions of MOODS stations during 1930-97: (a) temperature and (b) salinity. 

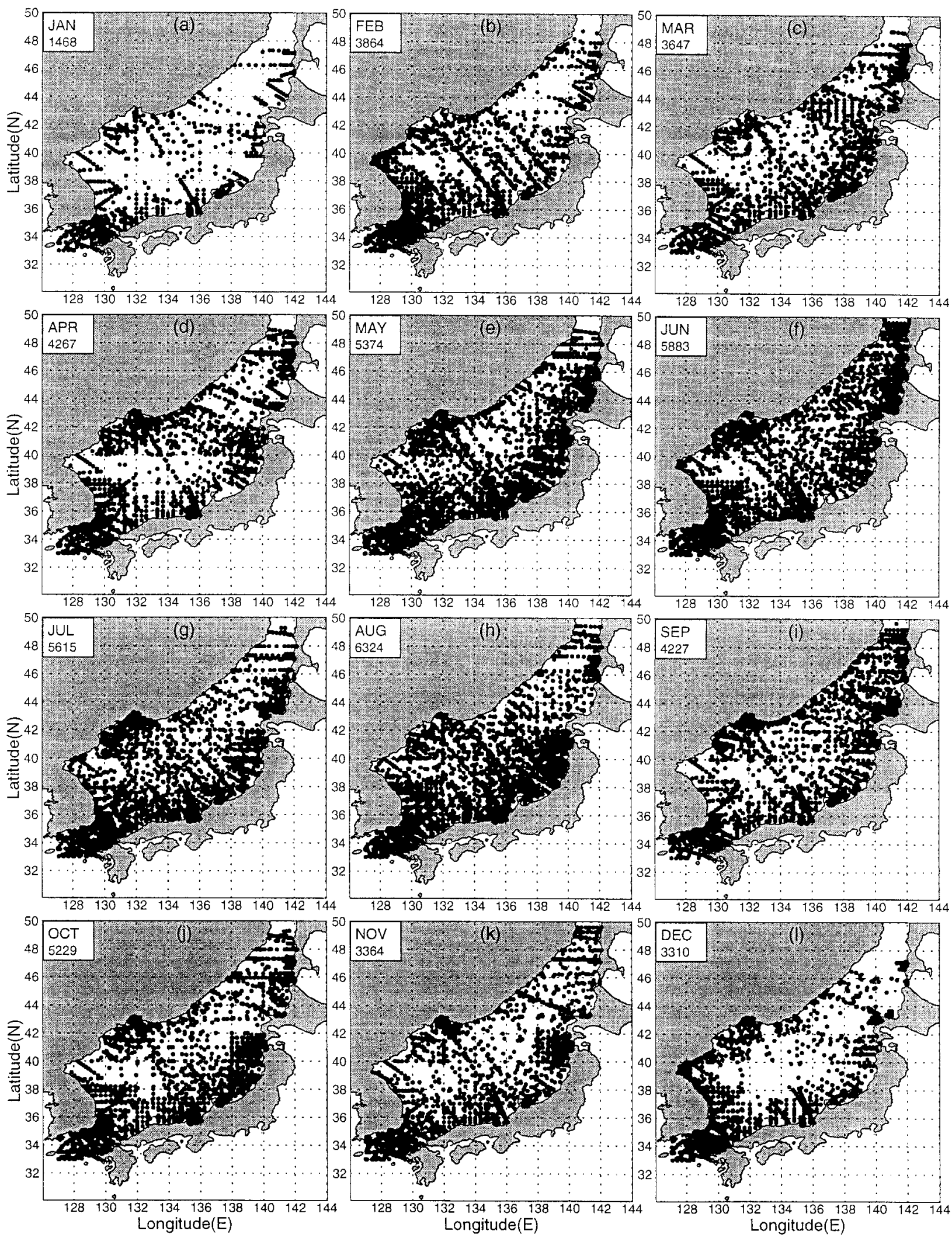

FIG. 2. (Continued) 

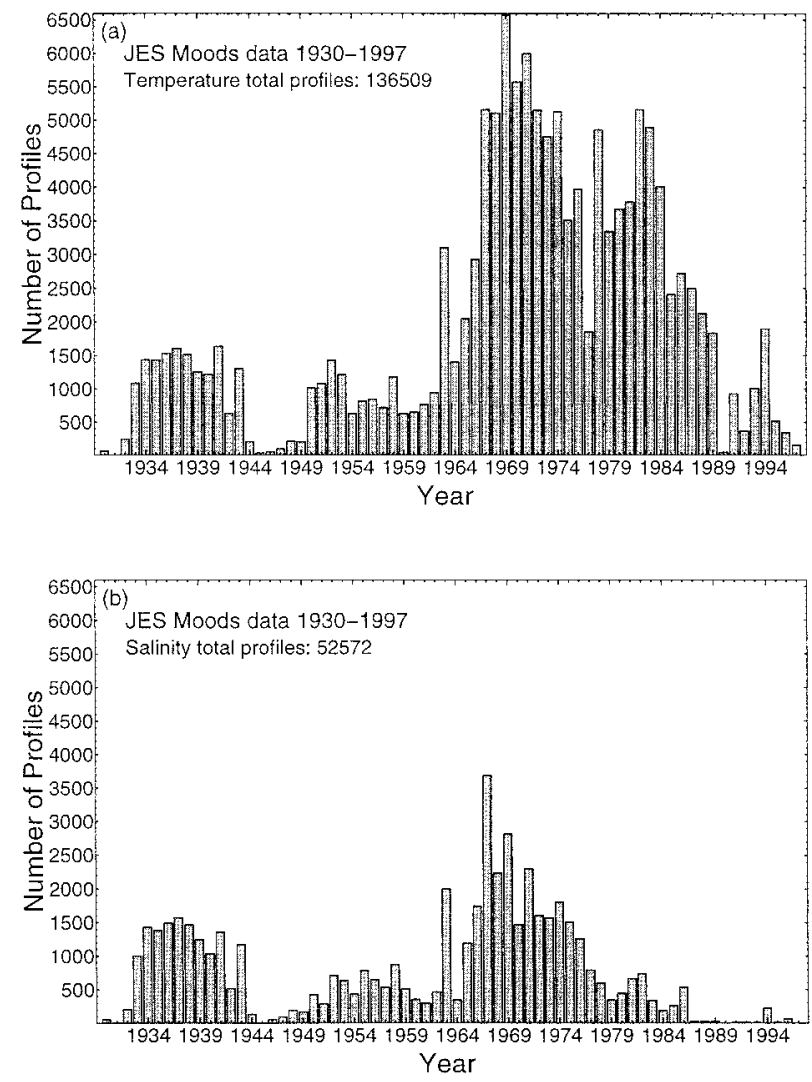

FIG. 3. Temporal distributions of MOODS stations during 193097: (a) temperature and (b) salinity.

center expands eastward to $138^{\circ} \mathrm{E}$ and occupies the midJES north of the SPF $\left(39^{\circ}-43^{\circ} \mathrm{N}\right)$ with the coldest center of $-9^{\circ} \mathrm{C}$ in February. The spring (Mar-May) pattern is featured by weakening of the mid-JES cold center. A typical summer anomaly pattern is featured by (i) all positive values and (ii) eastward expansion of a warm center from PGB. After the summer monsoon onset, a strong SST warm center $\left(8^{\circ} \mathrm{C}\right)$ occurs near PGB in July. The PGB warm center strengthens and expands eastward to $138^{\circ} \mathrm{E}$ and occupies the mid-JES north of the SPF $\left(39^{\circ}-43^{\circ} \mathrm{N}\right)$ with the warmest center of $11^{\circ} \mathrm{C}$ in August. The autumn (Sep-Oct) pattern is featured by weakening of the mid-JES warm center. The fact that the coldest (warmest) center occupies the mid-JES north of the SPF $\left(39^{\circ}-43^{\circ} \mathrm{N}\right)$ in winter (summer) suggests that the SST seasonal variability is greater in the north than in the south of the SPF. This result is consistent with an earlier analysis on the NCEP SST data (Chu et al. 1998b).

\section{b. Intermediate level $(150 \mathrm{~m})$}

The seasonal thermal variability at the 150-m depth is much weaker than that at surface (Fig. 6). The SPF still exists throughout the year and is located at almost the same location as at the surface. North of the SPF, the temperature is uniformly cold $\left(1^{\circ}-3^{\circ} \mathrm{C}\right)$ throughout the year. South of the SPF, the temperature changes from $5^{\circ} \mathrm{C}$ to $9^{\circ} \mathrm{C}$. The SPF meandering at $131^{\circ} \mathrm{E}, 134^{\circ} \mathrm{E}$, and $138^{\circ} \mathrm{E}$ forms several mesoscale eddies. The SPF meandering near Okin Gunto $\left(134^{\circ} \mathrm{E}\right)$ in spring was previously reported by Isoda and Saitoh $(1988,1993)$. Besides, a second front occurs (bifrontal structure) south of the SPF along the west coast of Japan during the winter and spring seasons.

Monthly mean temperature anomaly $T_{\text {an }}$ (Fig. 7) shows (i) a north-south asymmetric pattern with weaker seasonal variability north of rather than south of the SPF, and (ii) weakening of the SPF in the winter and strengthening of the SPF in the summer.

An evident cooling occurs south of the SPF from January to May (winter monsoon) with a large cold anomaly center $\left(T_{\text {an }}<-2^{\circ} \mathrm{C}\right)$ appearing in the $\mathrm{YB}\left(36^{\circ}-\right.$ $39^{\circ} \mathrm{N}, 132.5^{\circ}-136^{\circ} \mathrm{E}$ ) from March to April. Much weaker cooling appears north of the SPF during the same period (Jan-May). Such a differential cooling causes the northward increase of $T_{\text {an }}$ across the SPF, which implies the reduction of the SPF strength.

An evident warming occurs south of the SPF from June to October (summer monsoon) with a large warm anomaly center $\left(T_{\mathrm{an}}>2^{\circ} \mathrm{C}\right)$ appearing in the YB from August to September. Much weaker warming appears north of the SPF during the same period (Jun-Oct). Such a differential warming causes the northward decrease of $T_{\text {an }}$ across the SPF, which implies the enhancement of the SPF strength.

\section{c. Zonal cross sections $\left(37^{\circ}\right.$ and $\left.43^{\circ} \mathrm{N}\right)$}

The zonal cross sections $\left(37^{\circ}\right.$ and $\left.43^{\circ} \mathrm{N}\right)$ of monthly mean temperature show a strong seasonal/permanent thermocline structure south of the SPF (Fig. 8a) and a strong seasonal/weak permanent thermocline structure north of the SPF (Fig. 8b).

South of the SPF at $37^{\circ} \mathrm{N}$ (Fig. 8a), a permanent thermocline is located at $80-125 \mathrm{~m}$ and appears year-round with the maximum strength $\left(0.12^{\circ} \mathrm{C} \mathrm{m}^{-1}\right)$ in August. Above it, the seasonal thermocline occurs from the surface to $50-\mathrm{m}$ depth in June $\left(0.15^{\circ} \mathrm{C} \mathrm{m}^{-1}\right)$, intensifies during the summer monsoon season to a maximum value of around $0.36^{\circ} \mathrm{C} \mathrm{m}^{-1}$ in August, and weakens in September. In October, the seasonal thermocline erodes and an ocean mixed layer (OML) is formed. In November, the OML is well established with the temperature near $18^{\circ} \mathrm{C}$ and the depth around $75 \mathrm{~m}$. During the prevailing winter monsoon season (Dec-Mar), the OML deepens to $80-130 \mathrm{~m}$ with a westward uplift of the OML depth: $80 \mathrm{~m}$ near the Korean coast and $130 \mathrm{~m}$ near the Japanese coast. The OML temperature is around $10^{\circ} \mathrm{C}$. The OML starts to warm at a rate of $2^{\circ} \mathrm{C}$ month $^{-1}$ from March to May, and its depth shoals, respectively. For example, the OML temperature increases from $12^{\circ} \mathrm{C}$ in April to $14^{\circ} \mathrm{C}$ in May, and the OML depth decreases from 50$70 \mathrm{~m}$ in April to less than $50 \mathrm{~m}$ in May. This process 

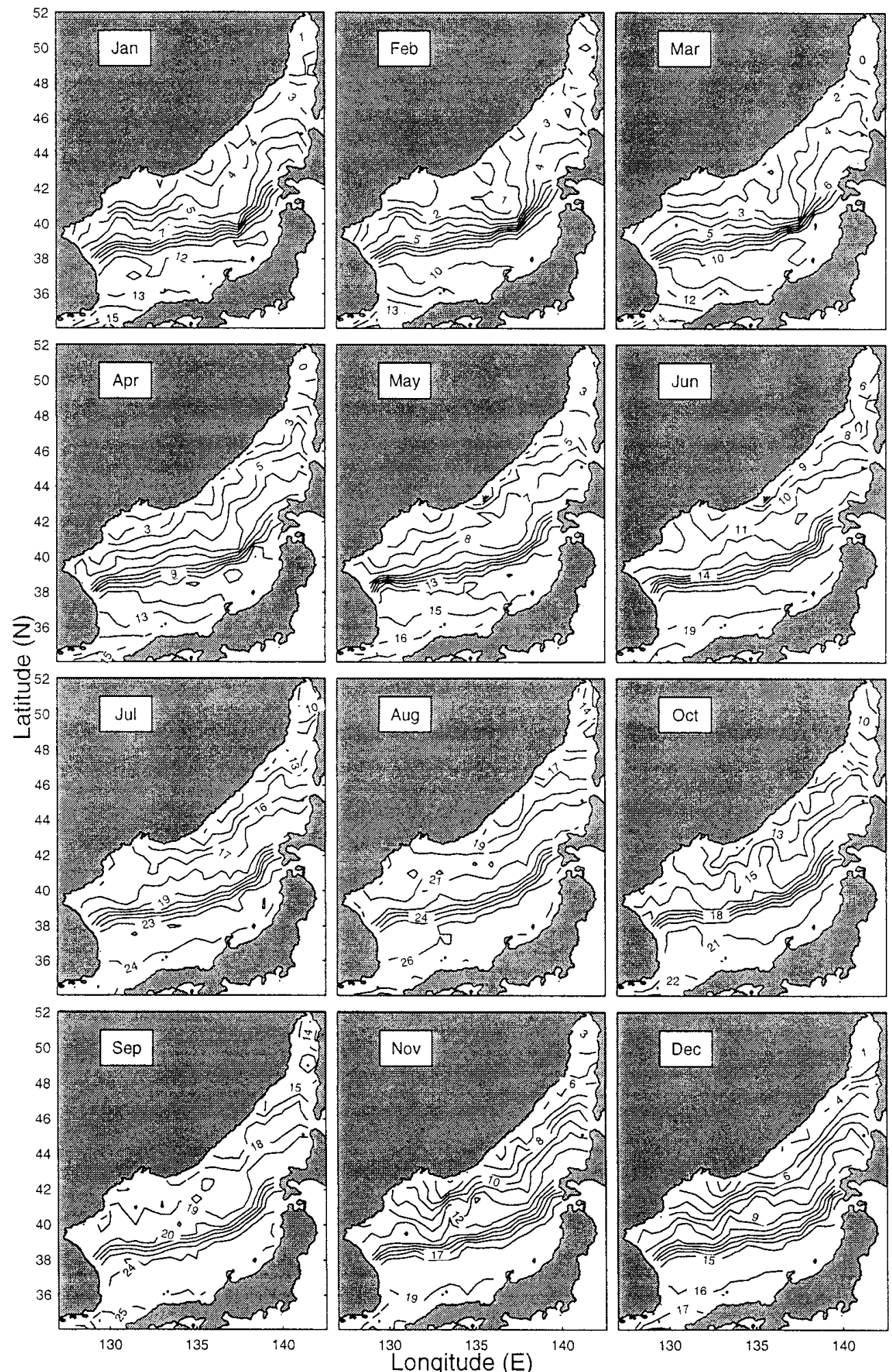

FIG. 4. Monthly mean temperature $\left({ }^{\circ} \mathrm{C}\right)$ field at the ocean surface. 

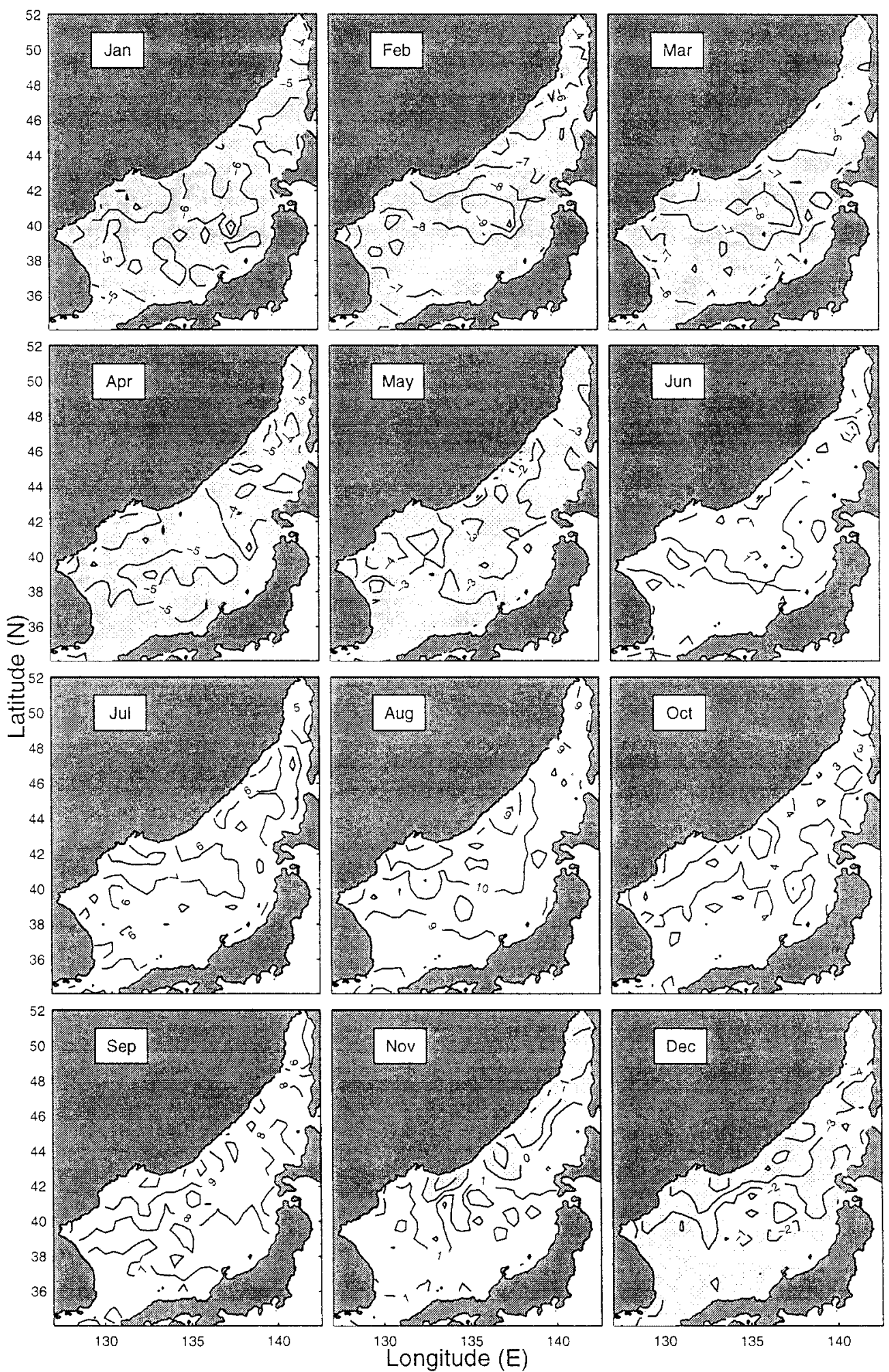

FIG. 5. Monthly mean temperature anomaly $\left({ }^{\circ} \mathrm{C}\right)$ field at the ocean surface. Negative values are shaded. 

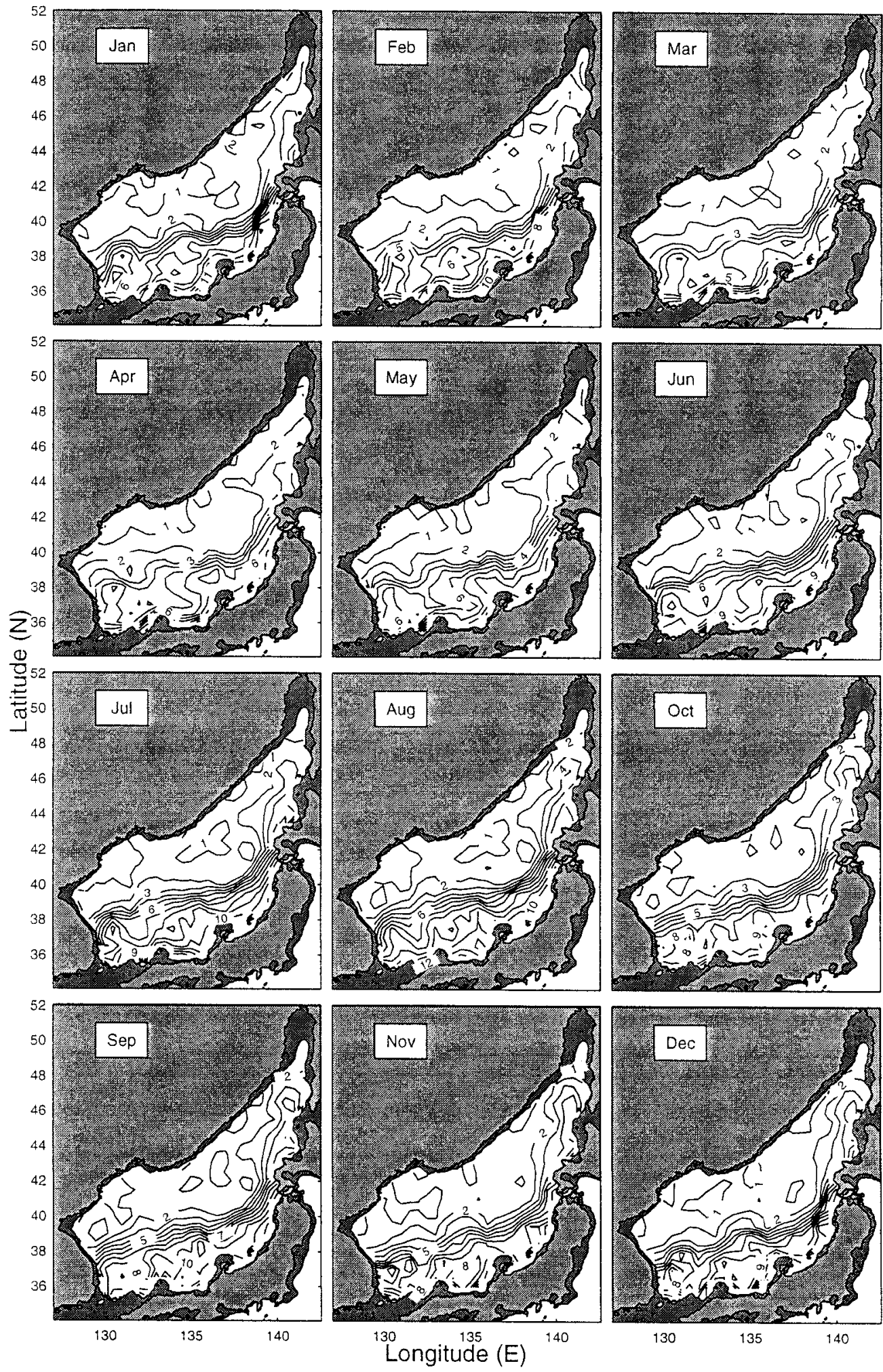

Fig. 6. Monthly mean temperature $\left({ }^{\circ} \mathrm{C}\right)$ field at $150-\mathrm{m}$ depth. 

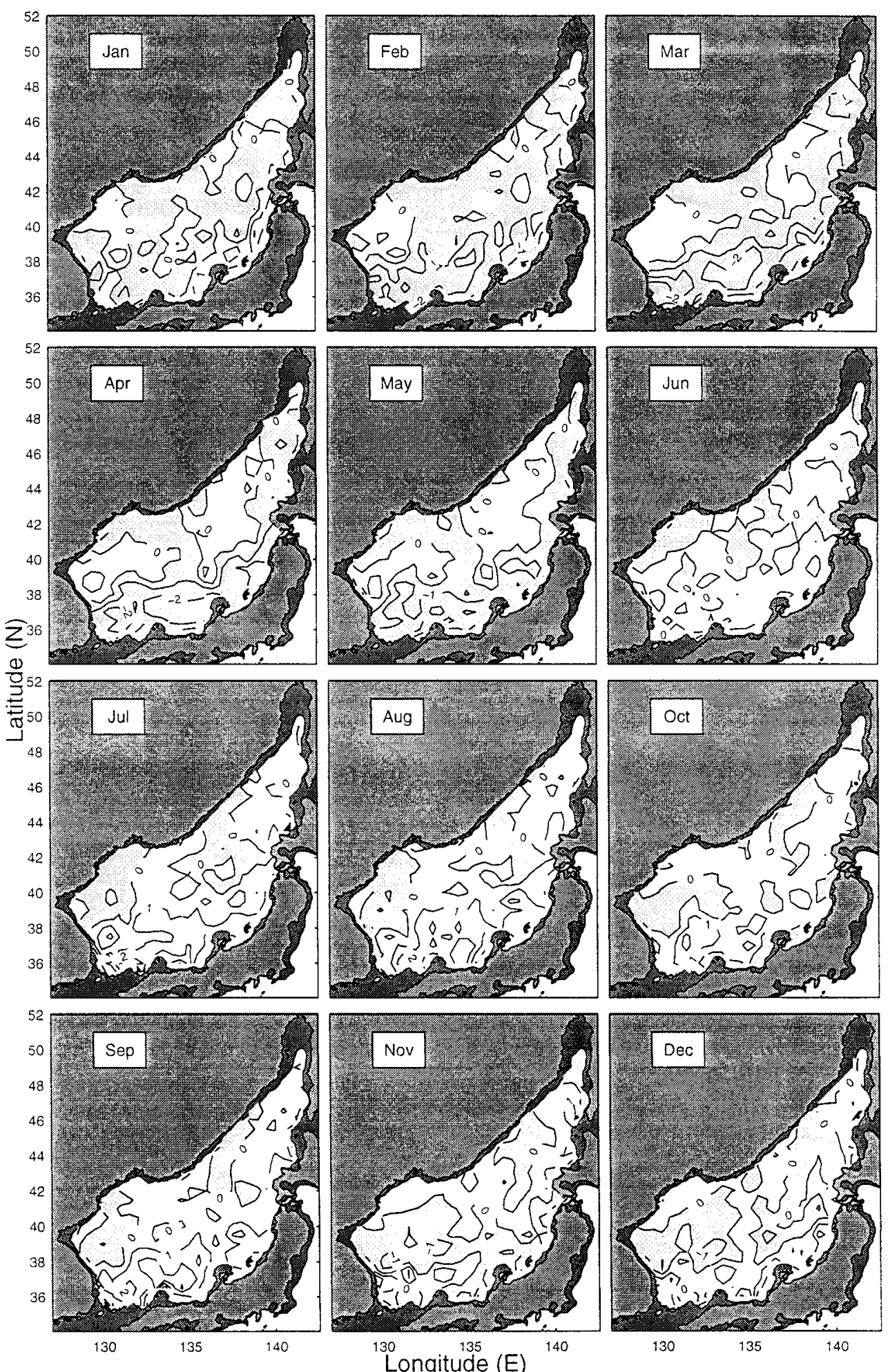

FIG. 7. Monthly mean temperature anomaly $\left({ }^{\circ} \mathrm{C}\right)$ field at $150-\mathrm{m}$ depth. Negative values are shaded. 
(OML warming and shoaling) continues during the summer monsoon season (Jun-Aug).

North of the SPF at $43^{\circ} \mathrm{N}$ (Fig. 8b), the permanent thermocline is quite weak and located near the surface to 300-m depth with an evident westward uplift from the Japanese coast (thickness around $300 \mathrm{~m}$ ) to the Russian coast (thickness around $100 \mathrm{~m}$ ). The seasonal thermocline occurs from the surface to 50-m depth in May $\left(\sim 0.08^{\circ} \mathrm{C} \mathrm{m}^{-1}\right)$, intensifies during the summer monsoon season to a maximum value of around $0.5^{\circ} \mathrm{C} \mathrm{m}^{-1}$ in August and September, and weakens in October. In November, the seasonal thermocline erodes and becomes part of the permanent thermocline, which weakens during the prevailing winter monsoon season. In February, the permanent thermocline is so weak that the water column is almost uniformly cold $\left(1^{\circ} \mathrm{C}\right)$ west of $136^{\circ} \mathrm{E}$ and weakly stratified $\left(\leq 0.01^{\circ} \mathrm{C} \mathrm{m}^{-1}\right)$ east of $136^{\circ} \mathrm{E}$.

\section{d. Latitudinal cross section $\left(135^{\circ} \mathrm{E}\right)$}

The strong north-south thermal asymmetry across the SPF is also identified from a latitudinal cross section $\left(135^{\circ} \mathrm{E}\right)$ of the monthly mean temperature (Fig. 9).

During the prevailing winter monsoon season (DecMar), the permanent thermocline is identified at 100$250 \mathrm{~m}$ depths south of the SPF with a vertical temperature gradient weakening from December (near $0.1^{\circ} \mathrm{C}$ $\mathrm{m}^{-1}$ ) to March (near $0.05^{\circ} \mathrm{C} \mathrm{m}^{-1}$ ). The permanent thermocline is identified at $25-100-\mathrm{m}$ depths north of the $\mathrm{SPF}$ in December with a vertical gradient near $0.06^{\circ} \mathrm{C}$ $\mathrm{m}^{-1}$, which is much weaker than that south of the SPF. From January to March, there is almost no evident thermocline north of the SPF.

During the prevailing summer monsoon season (JunAug), a shallow seasonal thermocline occurs in the whole JES basin with a much stronger strength north of rather than south of the SPF; and overlays relatively uniform water north of the SPF and stratified water (the permanent thermocline) south of the SPF. North of the SPF a seasonal thermocline appears near the surface (above 50-m depth) with a vertical gradient enhancing from $0.25^{\circ} \mathrm{C} \mathrm{m}^{-1}$ in June to $0.36^{\circ} \mathrm{C} \mathrm{m}^{-1}$ in August. This strong and shallow thermocline isolates the exchange of seawater below the thermocline from atmospheric forcing and makes this water (north of the SPF under the thermocline) quite uniform. South of the SPF a seasonal thermocline is wider (25-100-m depths) and weaker with a vertical gradient around $0.13^{\circ} \mathrm{C} \mathrm{m}^{-1}$. Such a north-south asymmetric pattern in July was previously presented by Kim and Kim (1999) using the Circulation Research of the East Asian Marginal Seas (CREAMS) data taken mainly in the summer of 1995. However, the seasonal thermocline north of the SPF is much stronger from the GDEM data than from the CREAMS-1995 data.

The seasonal thermocline has a strong asymmetry across the SPF. North of the SPF, the seasonal thermocline occurs near the surface in April and May, en- hances drastically during the summer monsoon season, survives in the fall, and is still quite strong with a vertical gradient of $0.12^{\circ} \mathrm{C} \mathrm{m}^{-1}$ in November. It weakens drastically in December. South of the SPF, the seasonal thermocline occurs in the summer monsoon season, survives in the early fall, and disappears in November.

\section{Salinity \\ a. Sea surface}

The monthly sea surface salinity (SSS) field (Fig. 10) shows a strong seasonal variation with less (more) horizontal variability in winter (summer). The saline $\mathrm{Ku}-$ roshio water ( $>34.2 \mathrm{psu}$ ) enters the JES from the Tsushima/Korean Strait into the JES and forms two permanent salty centers located in the northern JB (west of Hokkaido Island) with the salinity higher than $34.0 \mathrm{psu}$, and the area between UTB and YB with the maximum salinity of 34.3 psu in June, respectively. The northern JB salty center has less seasonal variation than the UTB/ YB salty center. Around the UTB/YB salty center, there are several fresh centers. The winter (Feb) field (Fig. $10)$ is consistent with that reported by Kim and Kim (1999, Fig. 9 in their paper) using the dataset of the Japan Oceanographic Data Center during 1930-90.

Three important features are found from the monthly SSS anomaly field (Fig. 11): (i) a basinwide positive (negative) anomaly occurs in the winter (summer); (ii) the seasonal variability of the surface salinity field is stronger in the south than in the north of the SPF; and (iii) there are two saline activity centers located at Tartar Strait and Tsushima Strait, respectively.

The SSS seasonal variation is characterized by the transition of the two patterns: the winter pattern (basinwide positive anomaly with the maximum value of 0.8 psu near Tsushima Strait in March) and the summer pattern (basinwide negative anomaly with the minimum value of -0.8 psu near Tsushima Strait in August-September). The winter pattern prevails in January-March, and the summer pattern prevails in July-September. The basinwide positive (negative) SSS anomaly in the winter (summer) might be caused by more (less) evaporation due to strong winter (weak summer) monsoon winds and less (more) precipitation.

In winter (Jan-Mar), two salty centers occur at both Tartar and Tsushima Straits, respectively. The positive Tartar Strait SSS anomaly is greater than 0.2 psu with a maximum value of 0.4 psu in January and February. The positive Tsushima Strait SSS anomaly is greater than 0.4 psu with a maximum value of 0.8 psu in March. The two saltier centers are caused by different physical processes: brine ejection due to ice freezing for the Tartar saltier center, and the intrusion of open ocean water for the Tsushima saltier center.

The spring (Apr-May) is characterized by the occurrence and southward expansion of a fresher (negative anomaly) center in Tartar Strait with a minimum value 

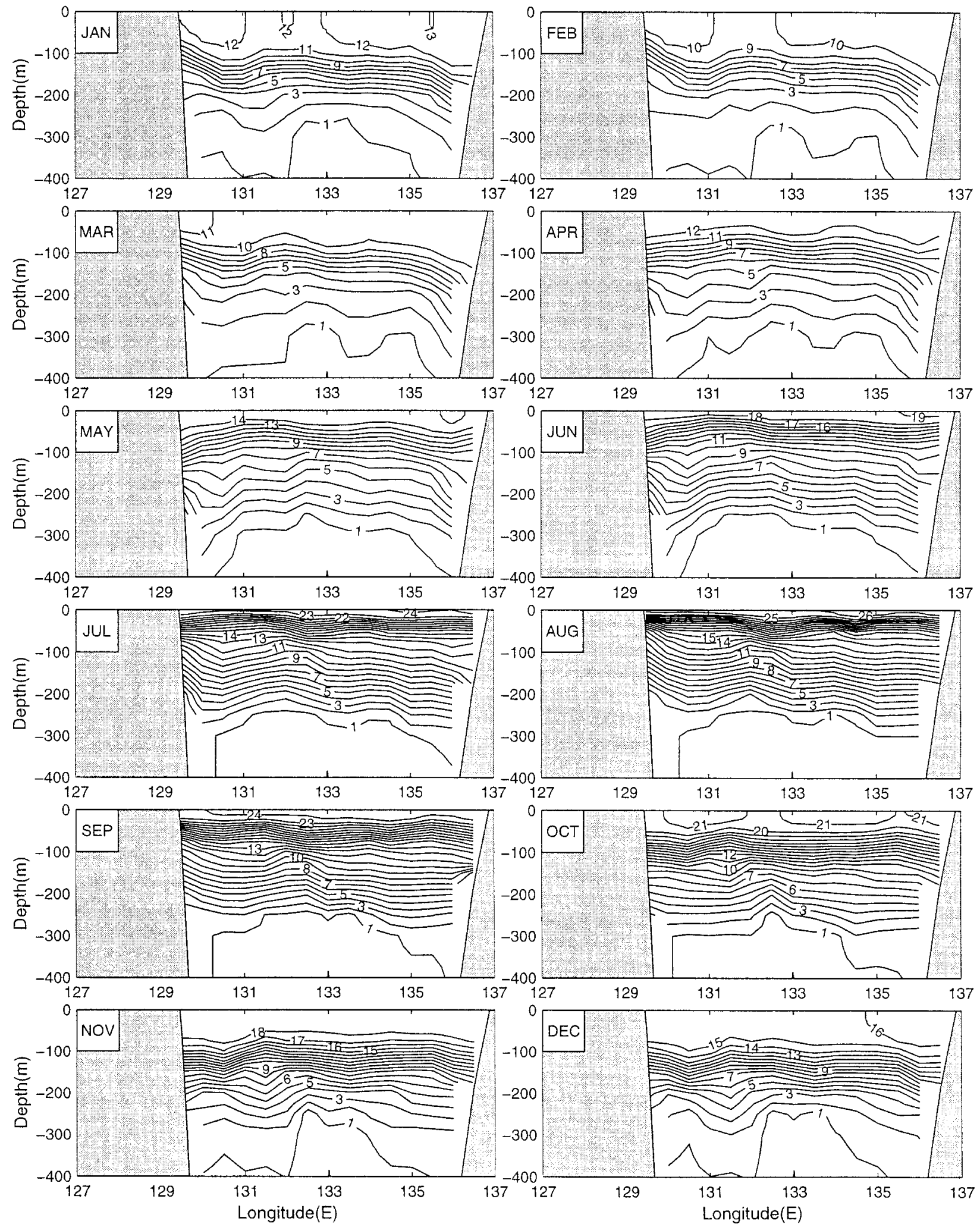

Fig. 8. Zonal cross section of the monthly mean temperature $\left({ }^{\circ} \mathrm{C}\right.$ ) at (a) $37^{\circ}$ and (b) $43^{\circ} \mathrm{N}$. Contour interval: $1{ }^{\circ} \mathrm{C}$. 

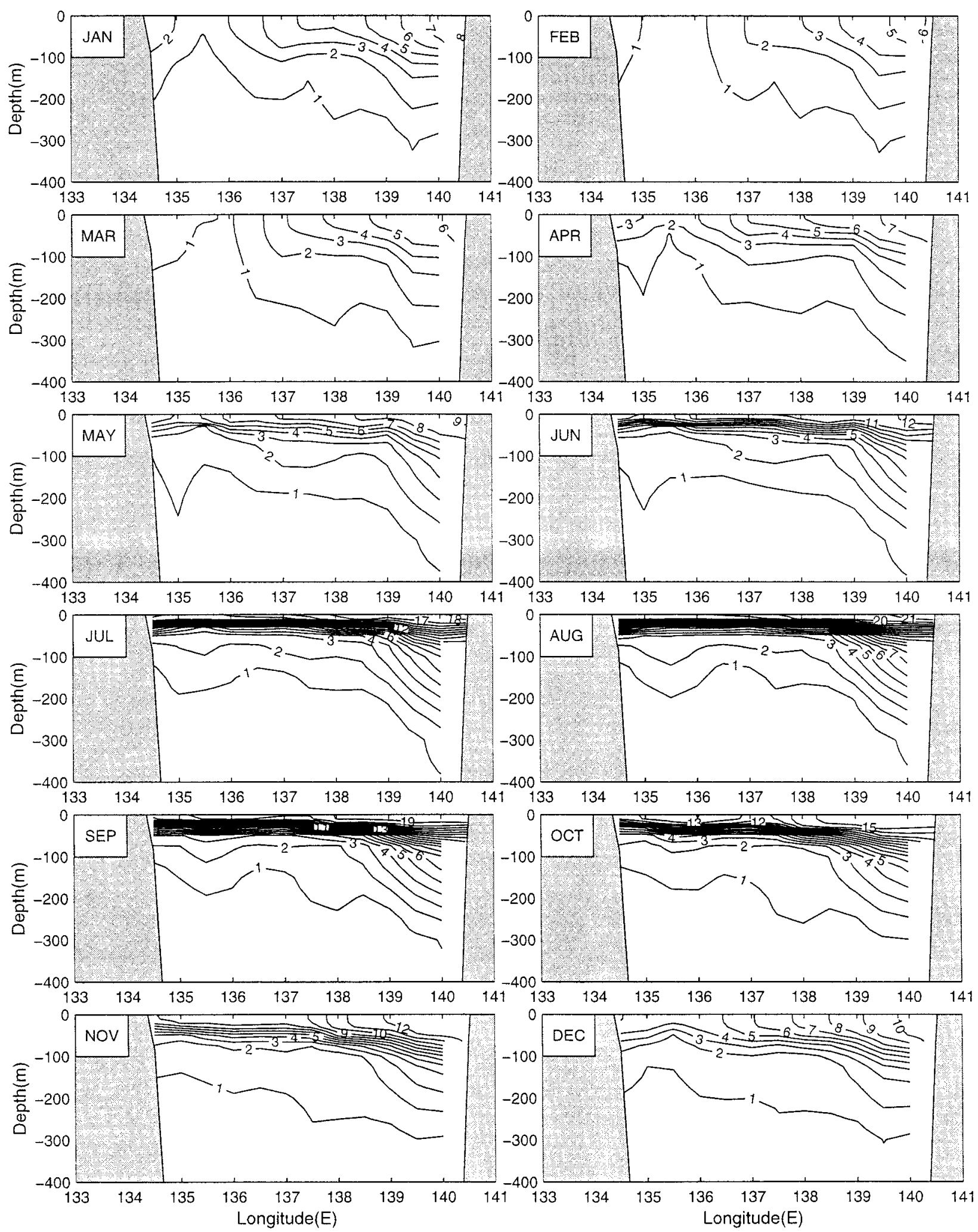

FIG. 8. (Continued) 

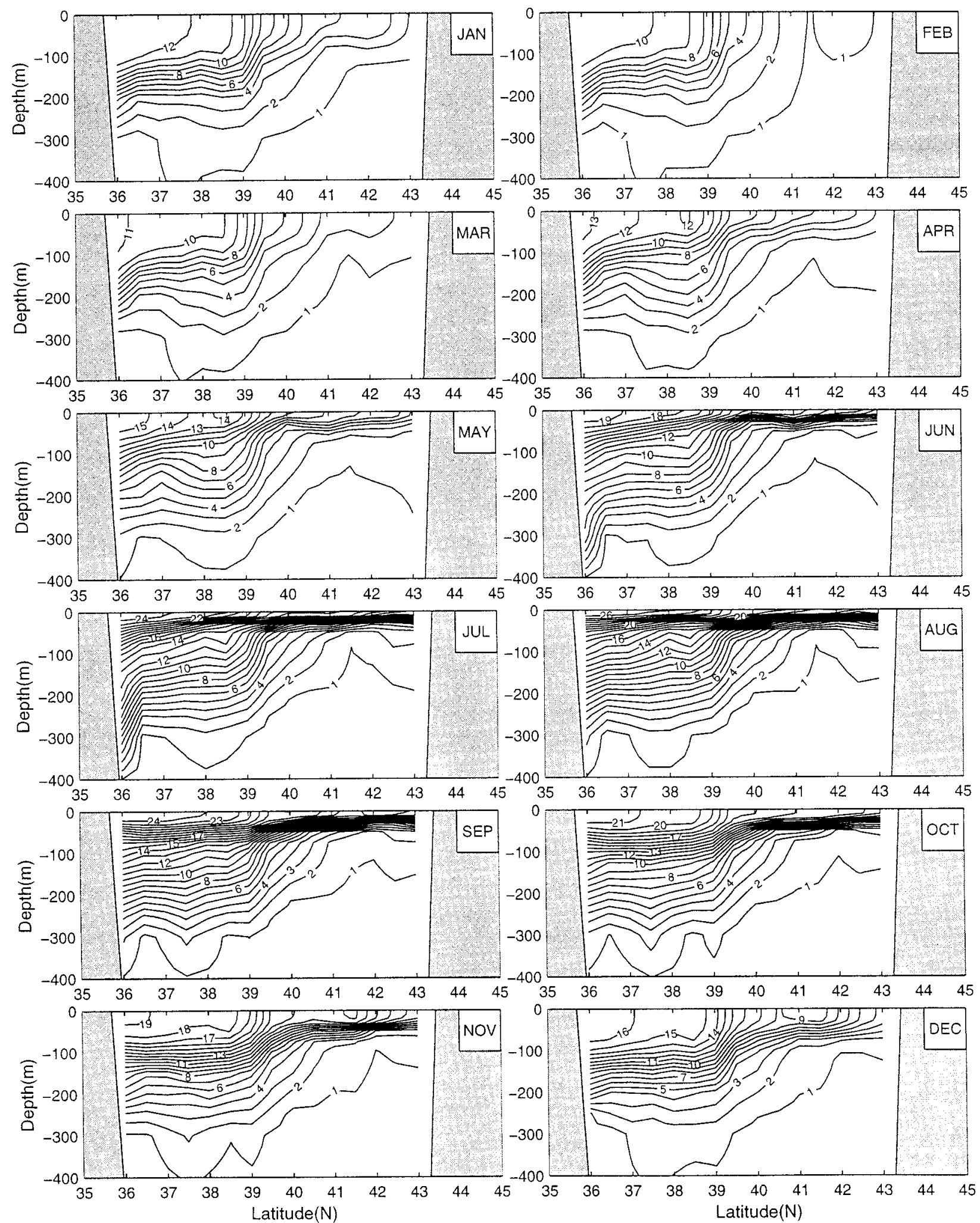

FIG. 9. Latitudinal cross section $\left(135^{\circ} \mathrm{E}\right)$ of the monthly mean temperature $\left({ }^{\circ} \mathrm{C}\right)$. Contour interval: $1^{\circ} \mathrm{C}$. 

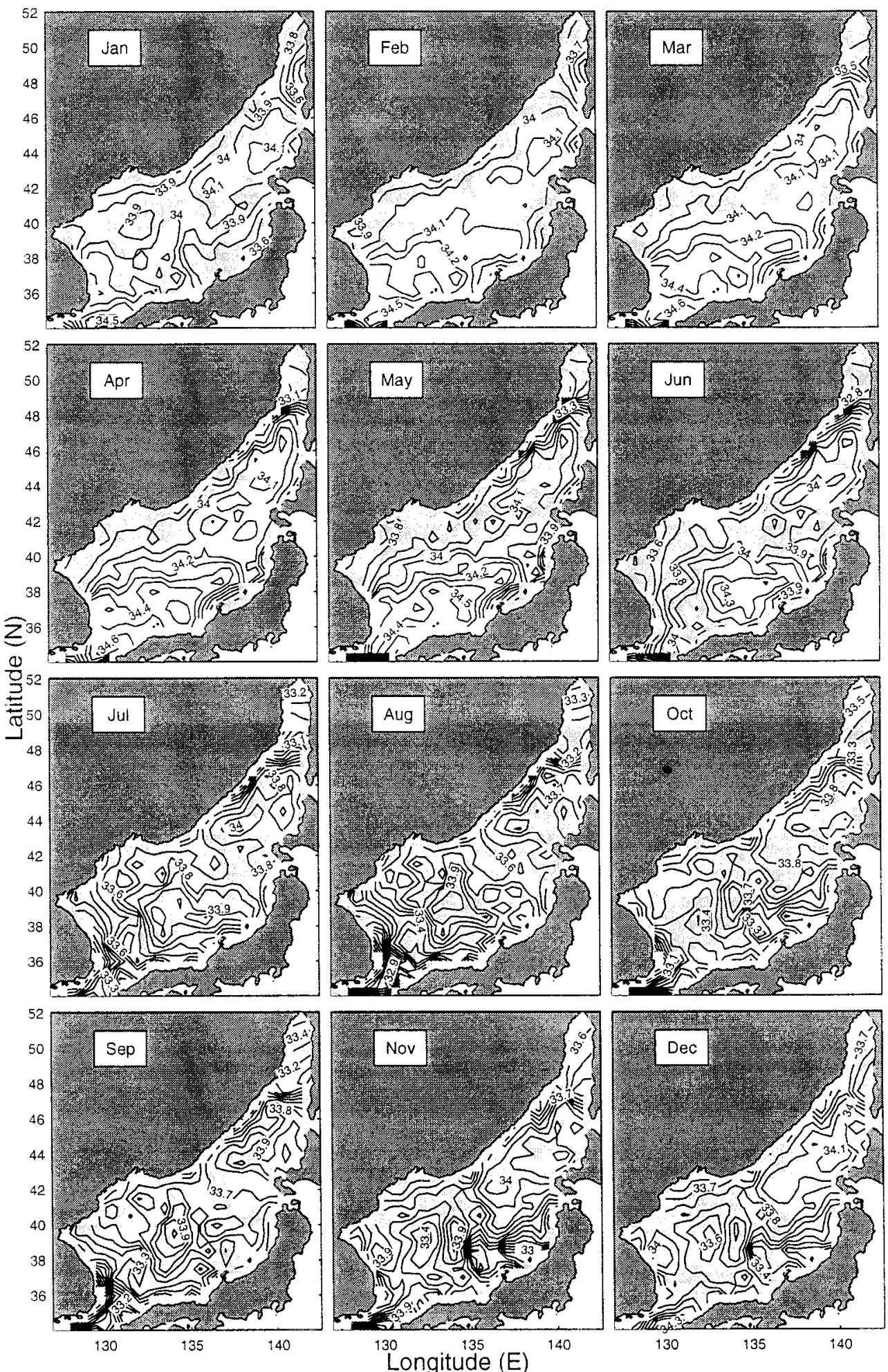

FIG. 10. Monthly mean salinity (psu) field at the ocean surface. Low salinity values $(S<34.06 \mathrm{psu})$ are shaded. 

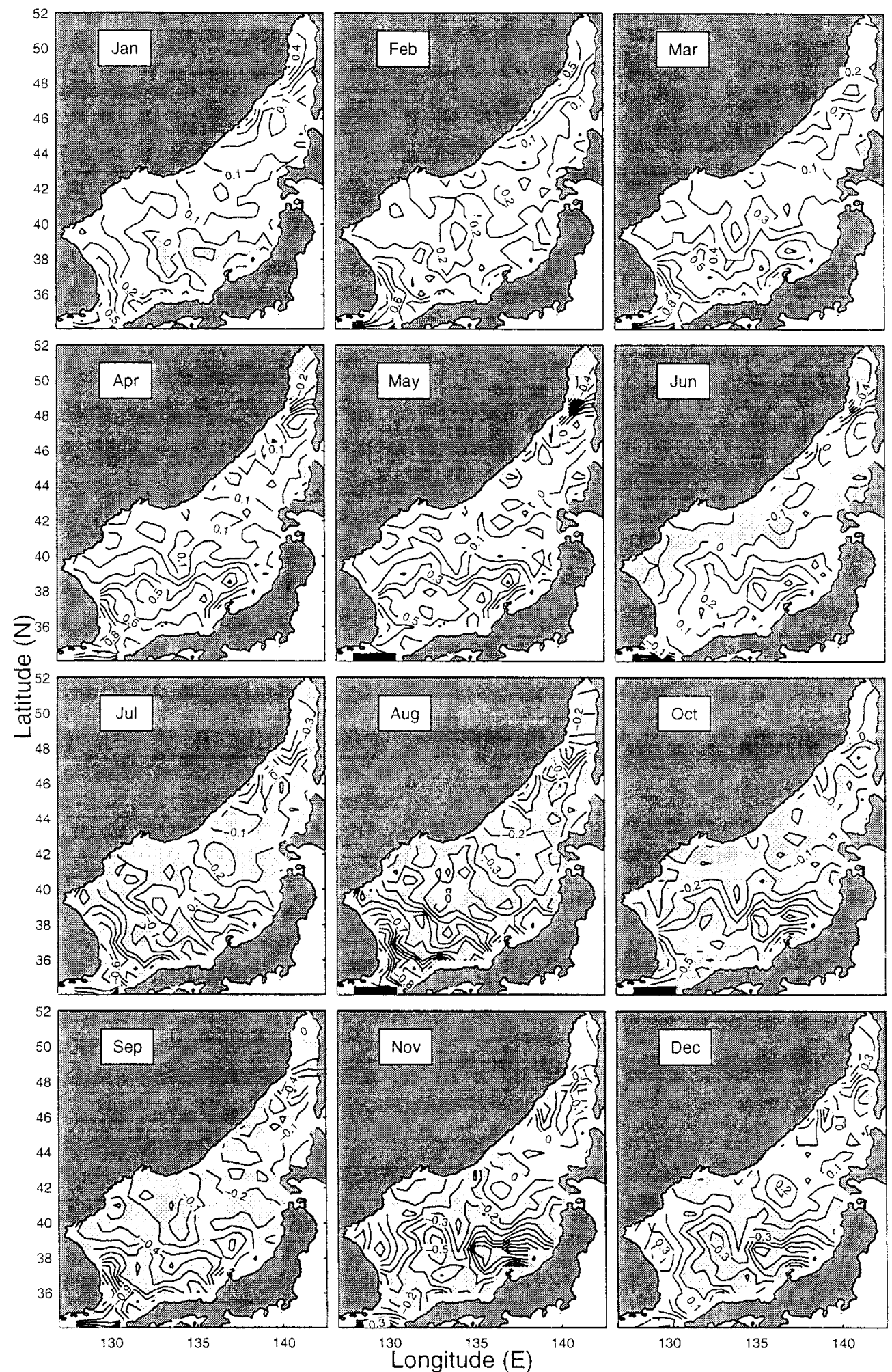

FIG. 11. Monthly mean salinity anomaly (psu) field at the ocean surface. Negative values are shaded. 
of -0.4 psu. Freshwater influx due to ice melting in the spring is responsible for the Tartar Strait negative anomaly.

In June, the negative salinity anomaly occupies north of the SPF, and another fresher center is formed near Tsushima Strait with a minimum value of $-0.6 \mathrm{psu}$ south of Tsushima Strait. The physical process causing this negative SSS anomaly is that in summer the Tsushima Current carries in a large amount of Yellow Sea water that is diluted by river runoff during the summer monsoon (Tomczak and Godfrey 1994). The northward expansion of this fresher anomaly into the JES basin leads to the summer SSS pattern.

In summer (Jul-Sep), a strong fresher center with a minimum value of -1.0 psu near Tsushima Strait expands northward and sweeps the whole JES with negative anomalies. The SSS anomaly is around $-0.2 \mathrm{psu}$ north of the SPF and from -0.2 to -1.0 south of the SPF.

The autumn (Oct-Nov) is characterized by the occurrence of two positive anomaly areas: one near Tartar Strait and the other near Tsushima Strait. The expansion of the two positive anomaly areas into the JES basin leads to the transition to the winter pattern.

\section{b. Intermediate level $(150 \mathrm{~m})$}

Figure 12 shows horizontal depictions of the monthly mean salinity at $150-\mathrm{m}$ depth with a contour interval of $0.1 \mathrm{psu}$. The depth of $150 \mathrm{~m}$ corresponds to the middle level of the JIW (low salinity) as well as the HSIW (high salinity). The low salinity water of the JIW less than 34.06 psu (shaded areas in Fig. 12) prevails in the western JB and the UTB. It expands eastward during the summer monsoon season (Jun-Sep) and retreats westward during the winter monsoon season (DecMar). The high salinity water of the HSIW occupies the eastern JB. This is consistent with earlier work by Kim and Kim (1999). The saline water occupies the east and south and less saline water appears in the north and west, especially at the northwestern boundary. The 34.1 isohaline is collocated with the SPF (Fig. 6) with the salinity above (below) 34.1 in the south (north) of the SPF. North of the SPF salinity is relatively uniform (34.0-34.1 psu) throughout the year. South of the SPF salinity changes from 34.1 to 34.5 psu.

Figure 13 shows horizontal depictions of the monthly mean salinity anomaly at $150-\mathrm{m}$ depth with a contour interval of $0.05 \mathrm{psu}$. The absolute values of the anomaly are less than 0.2 psu throughout the JES basin. The winter (Jan-Mar) pattern is featured by a major positive anomaly north of the SPF and negative anomaly south of the SPF. The summer (Jul-Sep) pattern seems a mirror image of the winter pattern: a major negative anomaly north of the SPF and positive anomaly south of the SPF. The spring and fall anomalies are transitions between the two patterns.

\section{c. Zonal cross sections $\left(37^{\circ}\right.$ and $\left.43^{\circ} \mathrm{N}\right)$}

Zonal cross sections $\left(37^{\circ}\right.$ and $\left.43^{\circ} \mathrm{N}\right)$ of the monthly mean salinity show an evident SMIN south of the SPF (Fig. 14a) and absence of a SMIN north of the SPF (Fig. 14b). This is consistent with many earlier studies such as Miyazaki (1952, 1953), Miyazaki and Abe (1960), Kim and Chung (1984), Senjyu (1999), and Kim and Kim (1999).

South of the SPF at $37^{\circ} \mathrm{N}$ (Fig. 14a), a strong (seasonal) halocline occurs from the surface to depth $30 \mathrm{~m}$ in June $\left(0.01 \mathrm{psu} \mathrm{m}^{-1}\right)$, intensifies during the summer monsoon season to a maximum value of around 0.03 psu $\mathrm{m}^{-1}$ in August, and weakens from September to December. In January, the halocline erodes and disappears. During the summer monsoon season (Jun-Sep), the SMIN shifts eastward from the UTB $\left(131^{\circ}-133^{\circ} \mathrm{E}\right)$ in June to the southern YB $\left(132^{\circ}-135^{\circ} \mathrm{E}\right)$ in July-September. A horizontally oriented SMAX $(S>34.2 \mathrm{psu})$ appears above the SMIN with the interface at depths 200-300 m. In October, this horizontally oriented SMAX is broken into two parts with each part enclosed by the 34.2 psu isohaline. A narrow relatively low salinity area, sandwiched by the two SMAX centers, occurs in the central UTB (near $132^{\circ} \mathrm{E}$ ) beneath depth 100 $\mathrm{m}$ and strengthens from November to January accompanying the erosion of the surface halocline. In January, the near-surface halocline disappears, the SMIN (enclosed by 34.1 psu isoline) appears in the UTB $\left(131^{\circ}-\right.$ $133^{\circ} \mathrm{E}$ ) and reaches the surface, and the two SMAX centers weaken (especially the western one). The SMIN expands horizontally, descending vertically, and becomes very evident in February. From February to June, the SMIN continues to descend. The top of the SMIN occurs at depths 150-200 $\mathrm{m}$ in February and at 200$300 \mathrm{~m}$ in April-June.

North of the SPF at $43^{\circ} \mathrm{N}$ (Fig. 14b), the SMIN shows up in the upper layer (above $100 \mathrm{~m}$ ) of the western JB (west of $136^{\circ} \mathrm{E}$ ) year-round. This is consistent with Kim and Kim's (1999) identification that the JIW in the western JB is characterized by low salinity $(S<34.06 \mathrm{psu})$. The high salinity water $(S>34.1 \mathrm{psu})$ of the HSIW appears in the central $\left(136^{\circ}-138^{\circ} \mathrm{E}\right)$ and the eastern $\left(138.5^{\circ}-140^{\circ} \mathrm{E}\right) \mathrm{JB}$. The eastern JB SMAX appears almost year-round except during the spring season (MarMay). The central JB SMAX is not as evident as the eastern one except in February and March.

\section{d. Latitudinal cross section $\left(135^{\circ} \mathrm{E}\right)$}

The strong north-south haline asymmetry across the SPF is also identified from a latitudinal cross section $\left(135^{\circ} \mathrm{E}\right)$ of the monthly mean salinity: the appearance (disappearance) of the SMIN south (north) of the SPF (Fig. 15).

South of the SPF, SMIN ( $S<34.06 \mathrm{psu}$ ) occurs during the summer monsoon season (Jul-Oct) underneath a horizontally oriented SMAX with a salty core $(S>$ 

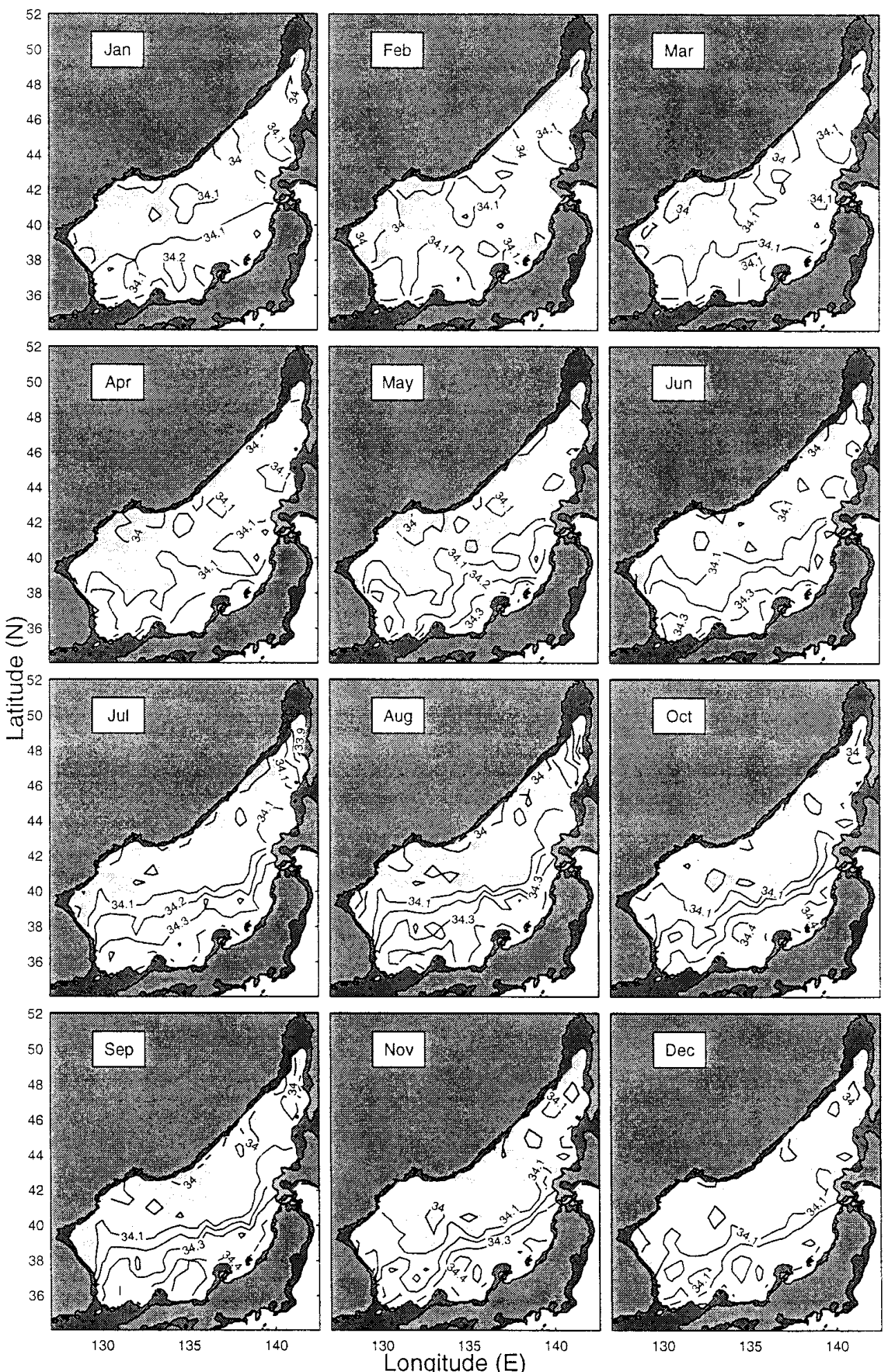

FIG. 12. Monthly mean salinity (psu) field at 150 -m depth. Low salinity values $(S<34.06 \mathrm{psu}$ ) are shaded. 

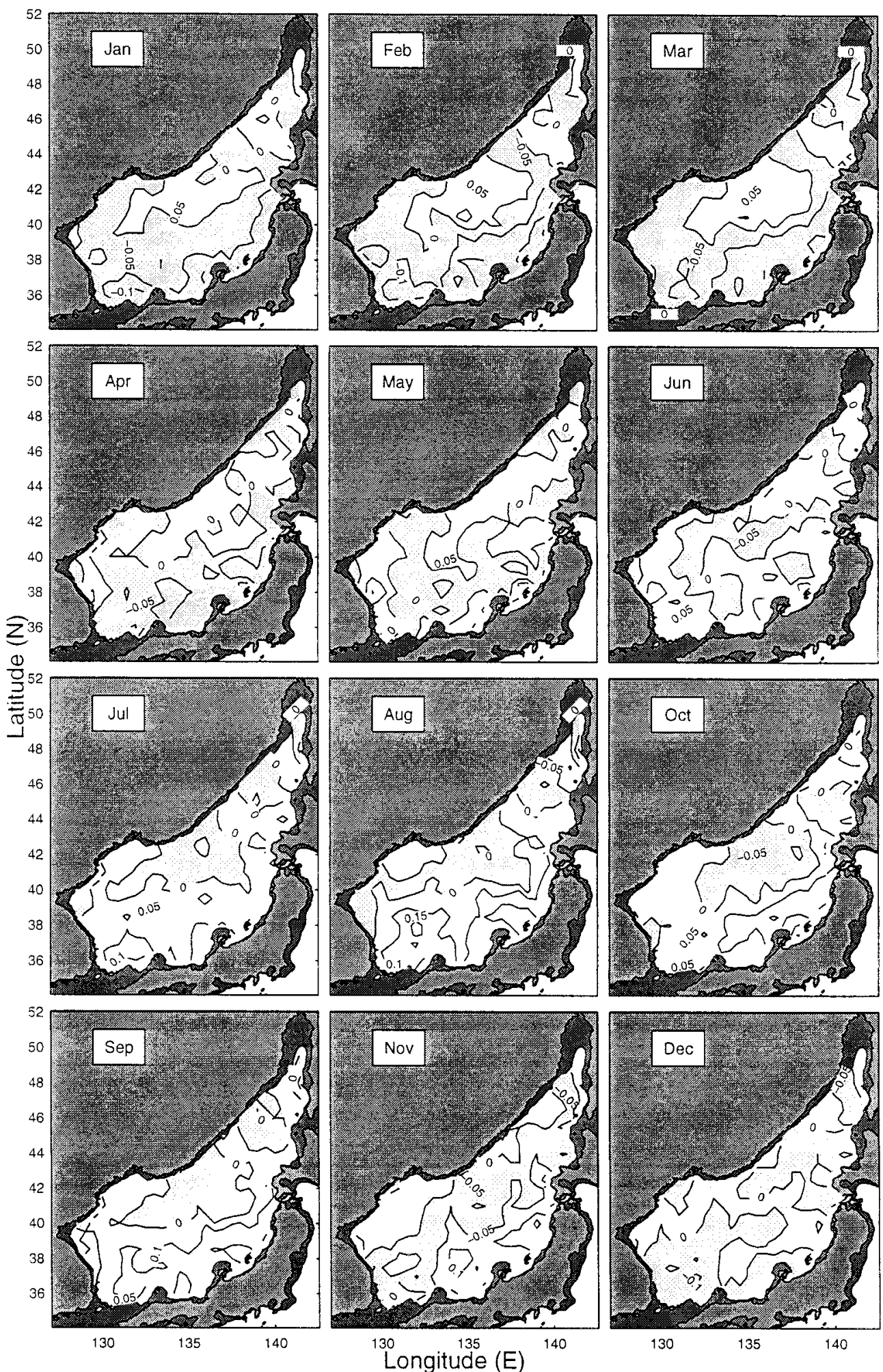

FIG. 13. Monthly mean salinity anomaly (psu) field at 150-m depth. Negative values are shaded. 

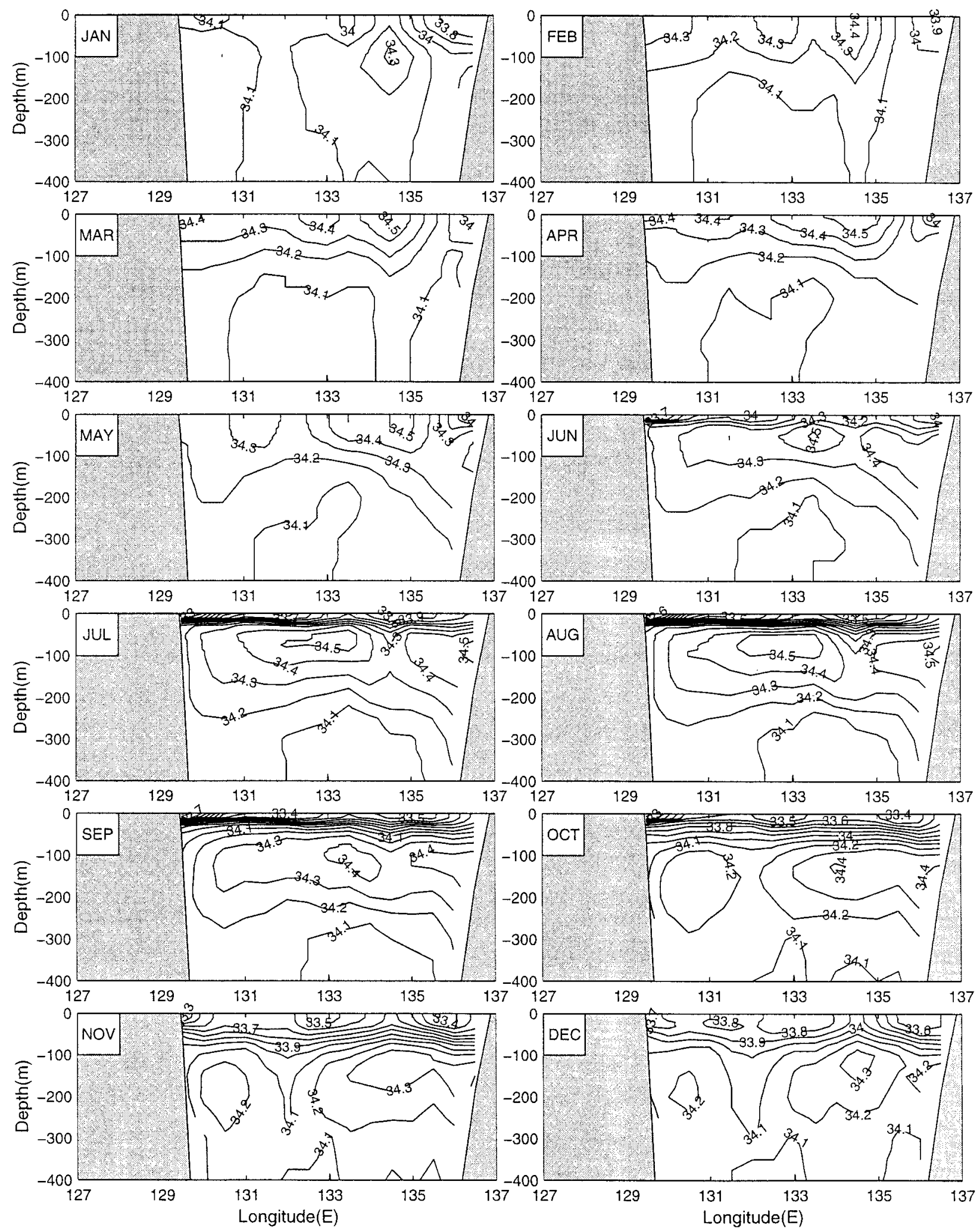

Fig. 14. Zonal cross section of the monthly mean salinity (psu) at (a) $37^{\circ}$ and (b) $43^{\circ} \mathrm{N}$. Contour interval: $0.1 \mathrm{psu}$. 

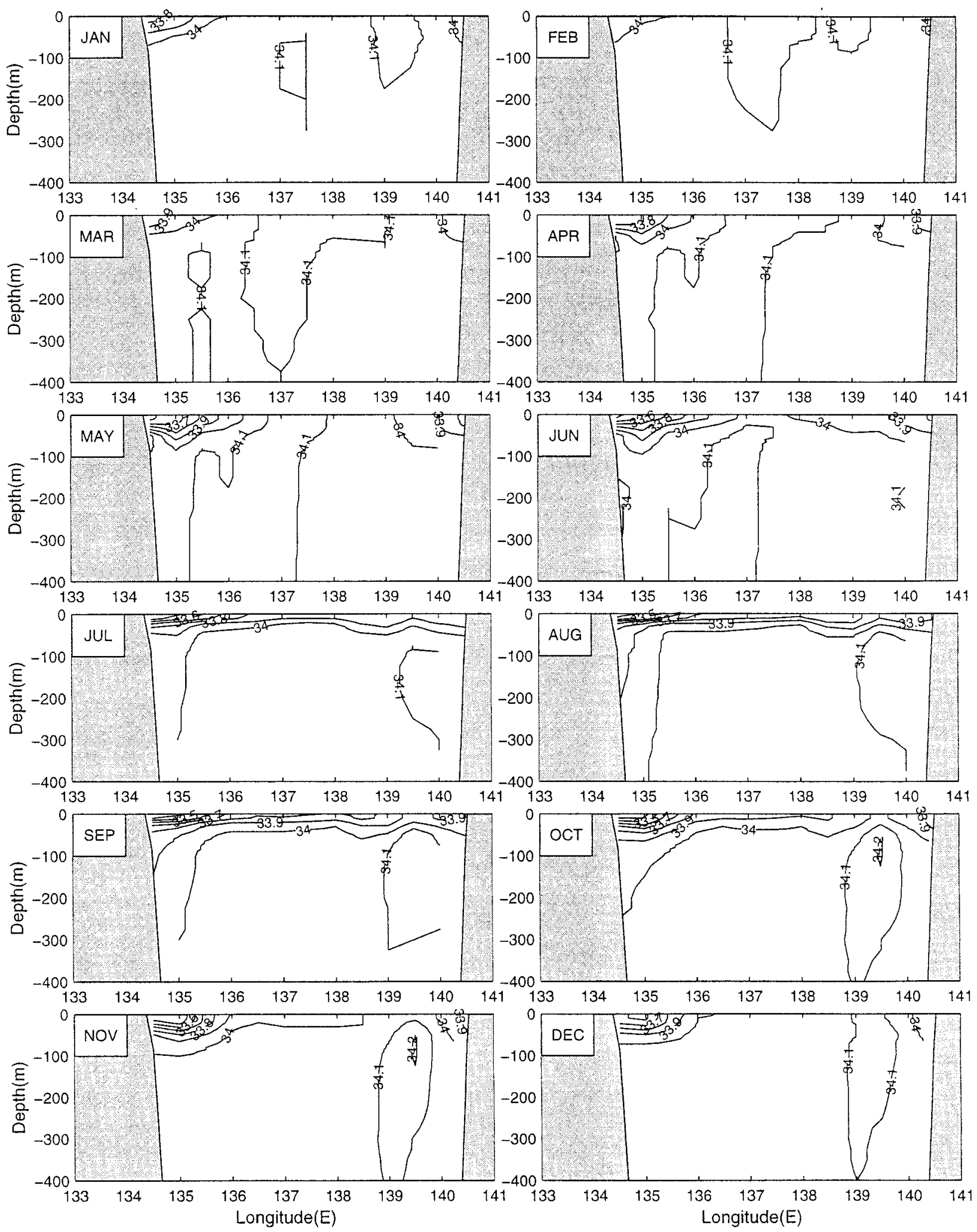

FIG. 14. (Continued) 

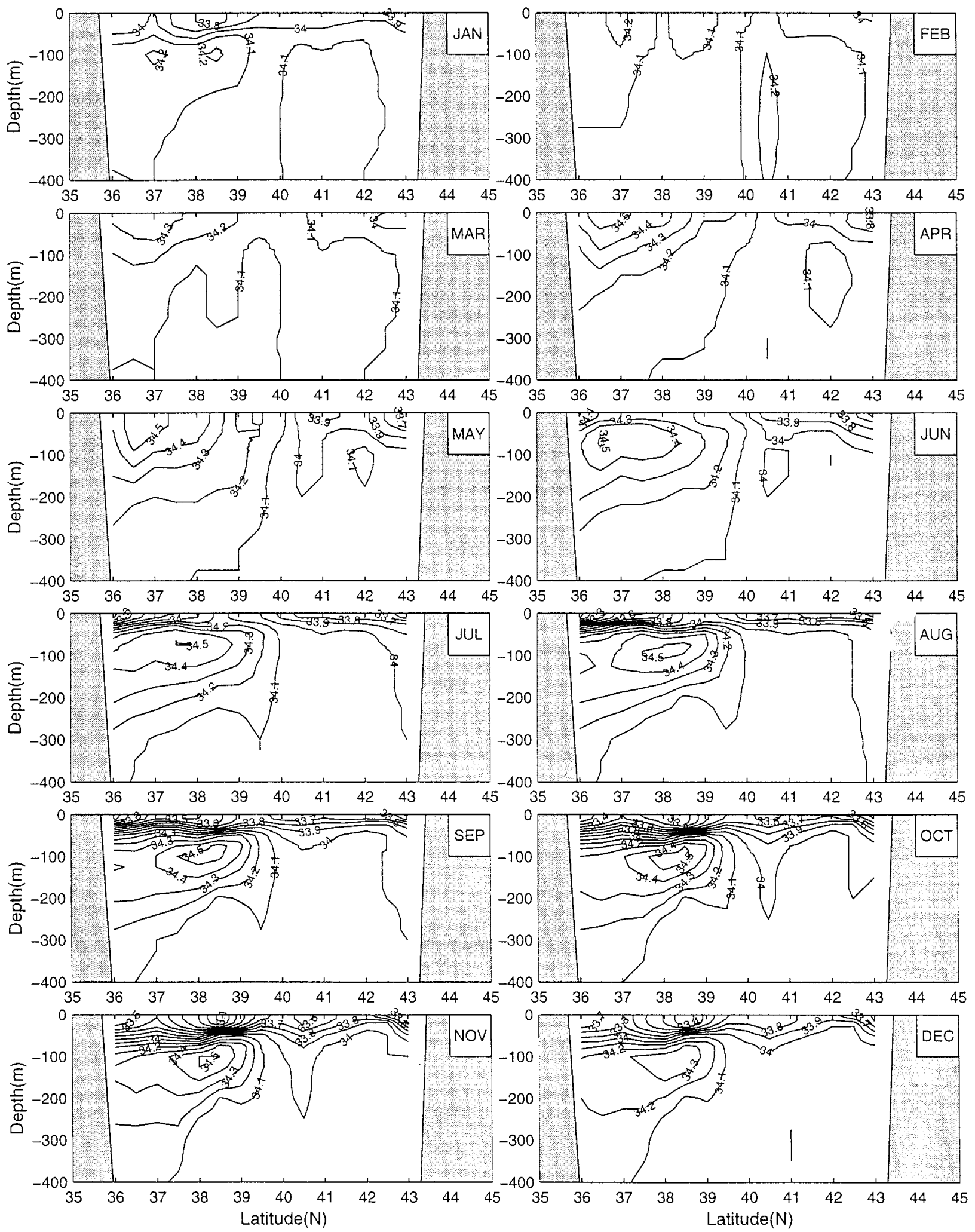

FIG. 15. Latitudinal cross section $\left(135^{\circ} \mathrm{E}\right)$ of the monthly mean salinity. Contour interval: $0.1 \mathrm{psu}$. 
$34.5 \mathrm{psu})$ at depth $100 \mathrm{~m}$. The SMAX with a salty core $(S=34.3 \mathrm{psu})$ was observed in October 1969 when a hydrographic survey for the whole JES basin was carried out by the Japan Meteorological Agency (Kim and Kim 1999). The interface between the SMIN and the SMAX is located at depth 200-300 m. During the winter monsoon season, the SMIN is not evident.

North of the SPF, high-salinity water $(S>34.1 \mathrm{psu})$ of the HSIW appears in the central JB $\left(40^{\circ}-43^{\circ} \mathrm{N}\right)$ with strengthening in the winter and weakening in the summer.

\section{Absolute geostrophic velocity}

The inverted absolute geostrophic velocity field (Fig. 16) coincides with earlier descriptions of the JES circulation (e.g., Uda 1934; Suda and Hidaka 1932; Suda et al. 1932; Suk 1988; Kim and Yoon 1996). However, the currents at the four major straits are not well inverted. For example, the velocity at the Tsushima/Korea Strait is too small, and there is no velocity inverted at the other straits such as Tartar Strait. This may be caused by the narrowness and shallowness of the straits.

The inverted absolute geostrophic velocity field shows an evident branching of the TWC. North of $35^{\circ} \mathrm{N}$, the TWC bifurcates into an eastern channel (first branch) and a western channel. The strength of the TWC at both channels reduces with depth. Flow through the western channel (i.e., EKWC) closely follows the Korean coast until it separates near $37^{\circ}-38^{\circ} \mathrm{N}$ into two branches: the offshore branch (or the second branch) follows the Polar Front to the western coast of Hokkaido Island and the alongshore branch (or the third branch) moves northward (i.e., the EKWC). Such a three-branch pattern was first identified by Suda and Hidaka (1932) and Suda et al. (1932) using hydrographic and current meter data from June to September in 1929 and in 1930, respectively. Since then, the existence of three branches has been believed to be the typical TWC flow pattern. Using temperature and salinity data mainly obtained in 1973, Kawabe (1982a) investigated the seasonal variation of the TWC branching and found that the first branch exists in spring and summer, the second branch only in summer from June to August, and the third branch in all seasons. His observational results were simulated using a twolayer numerical model (Kawabe 1982b; Sekine 1986).

The inverted flow through the eastern channel (first branch), which closely follows the Japanese coast (i.e., JNB), is weaker than the flow through the western channel (Fig. 16). The maximum speed of the first branch is found around $0.1 \mathrm{~m} \mathrm{~s}^{-1}$, occurring near the Japanese coast $\left(35.5^{\circ} \mathrm{N}, 135^{\circ} \mathrm{E}\right)$ at the surface. The JNB is too weak to be identified in the winter (Dec-Feb). In March, the JNB starts along the Japanese coast and strengthens in the spring and reaches its maximum velocity in July. This coincides with Kawabe's (1982a) observational results.

The inverted flow along the Polar Front (second branch) may be called the Polar Front Current (PFC). The maximum speed of the PFC is found at the surface around $0.2 \mathrm{~m} \mathrm{~s}^{-1}$ (Fig. 16). An asymmetric cyclonic gyre is found in the mid-JES $\left(38^{\circ}-44^{\circ} \mathrm{N}, 135^{\circ}-140^{\circ} \mathrm{E}\right)$ in the winter monsoon season (Dec-Mar) with the flow associated with the PFC at the southern and eastern flanks and the flow from the north (mid-JES cold current) at the northern and western flanks. The seasonal variability of this gyre is largely determined by the seasonal variability of the PFC. The PFC has a weak seasonal variation in flow pattern and a strong seasonal variation in current speed.

An interesting feature is the out-of-phase variation between the PFC (along the Polar Front) and the JNB (along the west coast of Japan). For example, the PFC (JNB) strengthens (weakens) from July to September, and the PFC (JNB) weakens (strengthens) in spring from March to April.

The seasonal variation of the JES major currents is also shown in the latitudinal cross section of the monthly mean $u$ component (Fig. 17). Two eastward flowing currents, the JNB (near $\left.36^{\circ} \mathrm{N}\right)$ and the PFC $\left(38^{\circ}-40^{\circ} \mathrm{N}\right)$, are well represented. The PFC has the maximum speed of $0.22 \mathrm{~m} \mathrm{~s}^{-1}$ (minimum speed of $0.12 \mathrm{~m} \mathrm{~s}^{-1}$ ) occurring in September (Feb-Apr) at the surface. During the summer monsoon season (Jul-Sep), the PFC strengthens (maximum speed increases from $0.18 \mathrm{~m} \mathrm{~s}^{-1}$ to $0.22 \mathrm{~m}$ $\mathrm{s}^{-1}$ ), and the JNB weakens (maximum speed decreases from $0.12 \mathrm{~m} \mathrm{~s}^{-1}$ to $0.04 \mathrm{~m} \mathrm{~s}^{-1}$ ). During the winter monsoon season (Dec-Apr), the PFC weakens (maximum speed decreases from $0.18 \mathrm{~m} \mathrm{~s}^{-1}$ to $0.12 \mathrm{~m} \mathrm{~s}^{-1}$ ), and the TWC strengthens (maximum speed increases from $0.02 \mathrm{~m} \mathrm{~s}^{-1}$ in January to $0.1 \mathrm{~m} \mathrm{~s}^{-1}$ in April). The PFC volume transport shows an evident seasonal variation with the maximum value of $1.32 \mathrm{~Sv}\left(\mathrm{~Sv} \equiv 10^{6} \mathrm{~m}^{3} \mathrm{~s}^{-1}\right)$ in November-December and the minimum value of 0.88 Sv in April (Fig. 18).

\section{Conclusions}

The goal of this study is to investigate the seasonal variabilities of the thermohaline structure and the circulation patterns of the JES using the public domain GDEM climatological hydrographic data. The major results from this research are summarized as follows:

1) The seasonal thermal variability is evident at the surface and weakens with depth. However, the SPF exists continuously through the year. Differential warming/cooling is found across the SPF. At the intermediate level (depth $150 \mathrm{~m}$ ), the SPF is situated almost at the same location as at the surface. The winter cooling (summer warming) is much stronger south of the SPF (anomaly larger than $2^{\circ} \mathrm{C}$ ) than north of the SPF (anomaly less than $1^{\circ} \mathrm{C}$ ). Such a differential cooling (warming) causes the northward increase (decrease) of temperature anomaly across the SPF, which implies the reduction (enhancement) of the SPF strength in the winter (summer). 


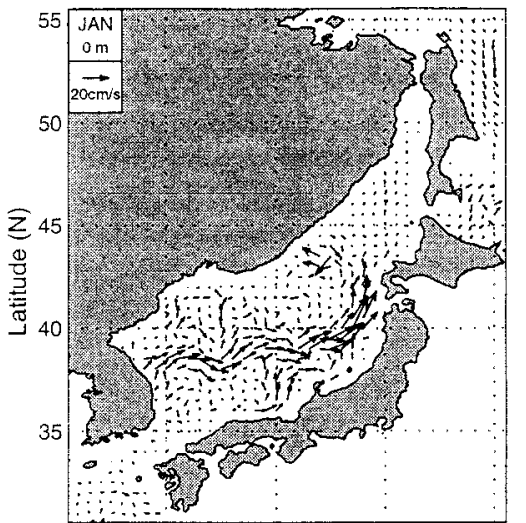

Currents in Japan Sea
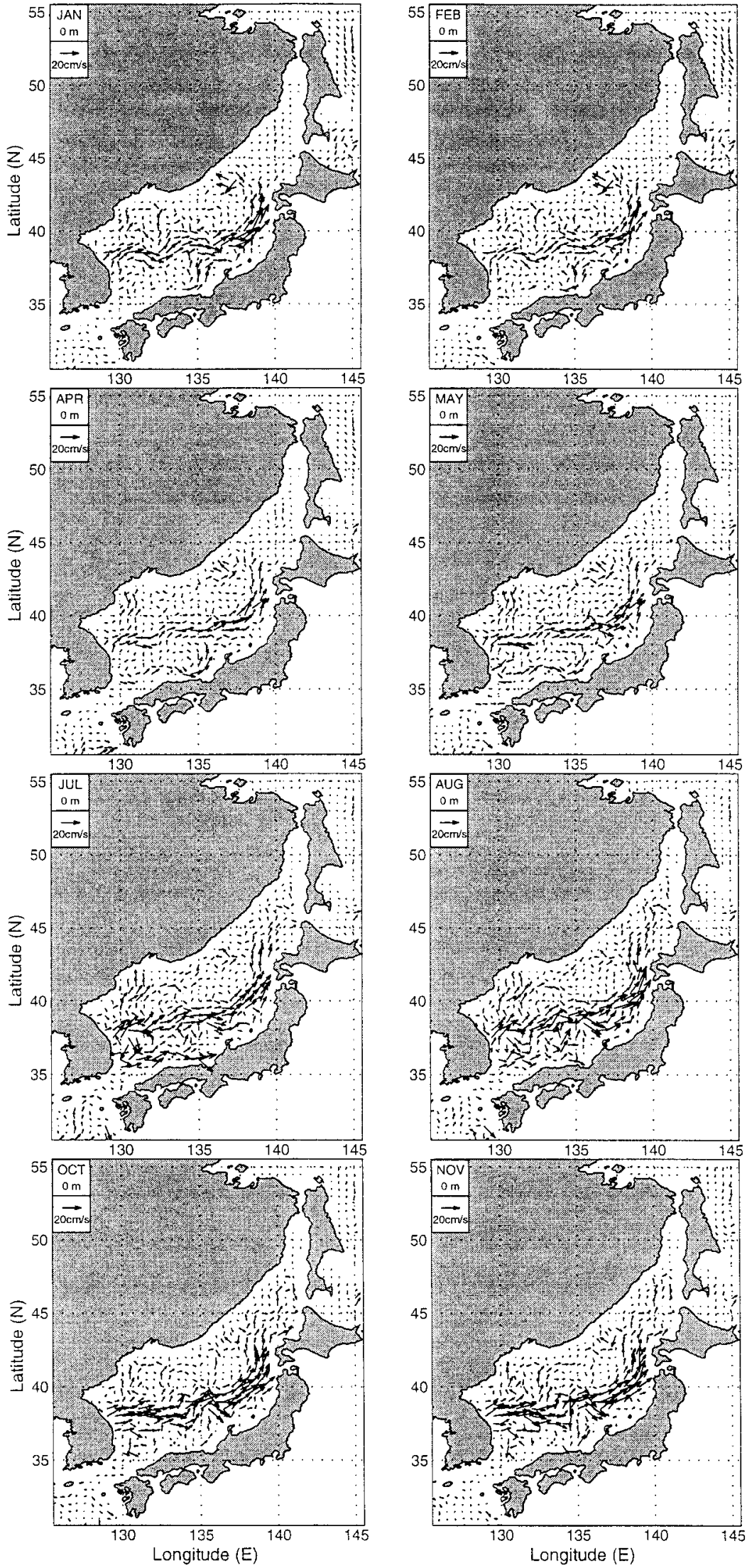
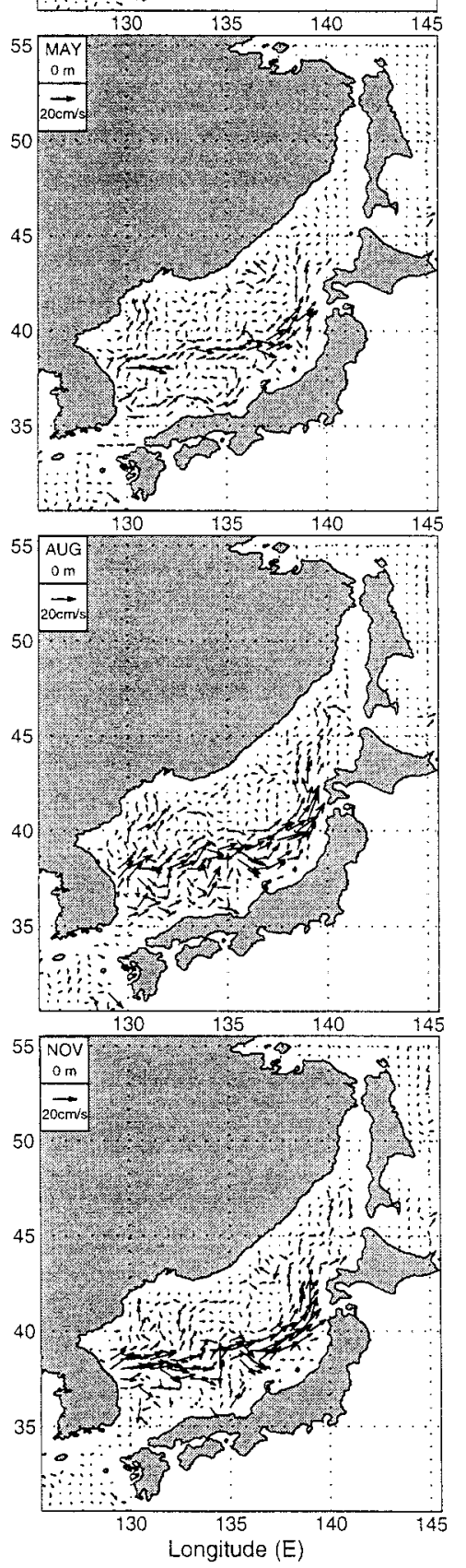
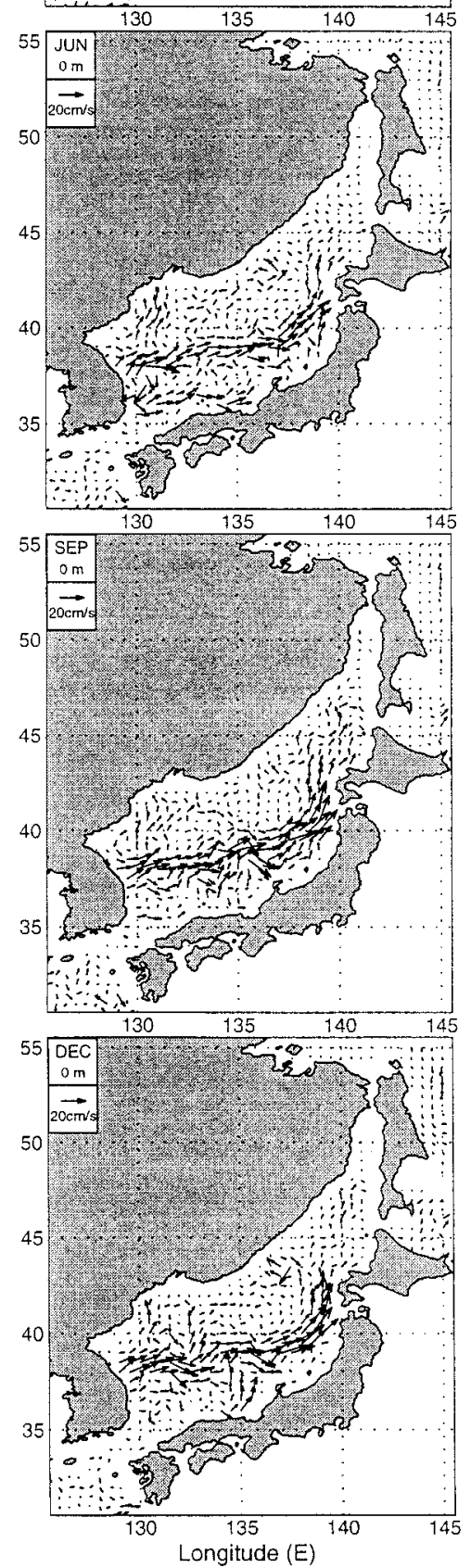

FIG. 16. Inverted monthly mean surface circulation. 

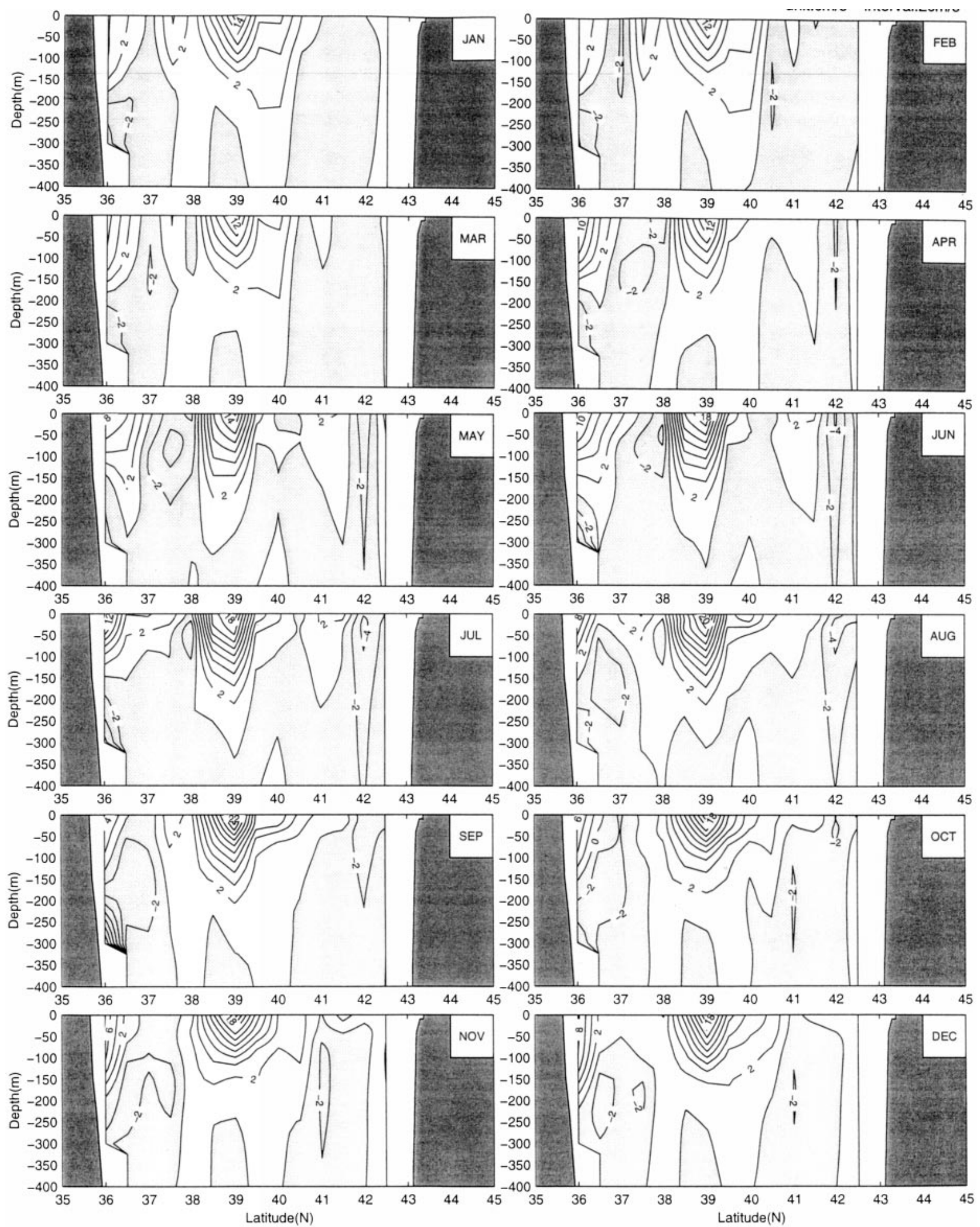

FIG. 17. Latitudinal cross sections of the inverted monthly mean $u$ velocity along $135^{\circ} \mathrm{E}$. Contour interval: $2 \mathrm{~cm} \mathrm{~s}^{-1}$. 


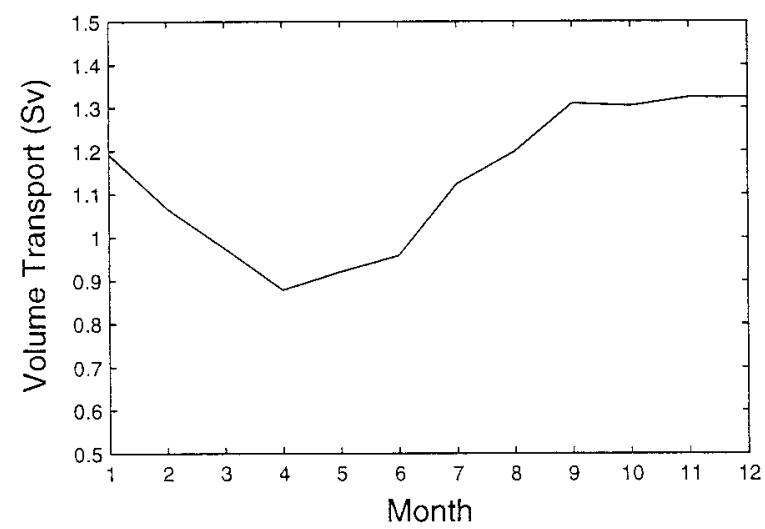

FIG. 18. Monthly variation of the volume transport (Sv) of the Polar Front Current at $135^{\circ} \mathrm{E}$ cross section.

2) The seasonal thermal variability has north-south asymmetry with a strong seasonal/weak permanent thermocline structure south of the SPF and a strong seasonal/weak permanent thermocline structure north of the SPF. South of the SPF, the permanent thermocline is located at depths 80-125 m appearing year-round with the maximum strength $\left(0.12^{\circ} \mathrm{C} \mathrm{m}^{-1}\right)$ in August. Above it, the seasonal thermocline occurs from the surface to depth $50 \mathrm{~m}$ in June $\left(0.15^{\circ} \mathrm{C} \mathrm{m}^{-1}\right)$, intensifies during the summer monsoon season to a maximum value of around $0.36^{\circ} \mathrm{C} \mathrm{m}^{-1}$ in August, and weakens in September. In October, the seasonal thermocline erodes and the ocean mixed layer forms and then deepens in winter. The ocean mixed layer starts to warm at a rate of $2^{\circ} \mathrm{C}$ month ${ }^{-1}$ from March to May, and its depth shoals.

North of the SPF, the permanent thermocline is quite weak and located near the surface to depth $300 \mathrm{~m}$ with an evident westward uplift from the Japanese coast (thickness around $300 \mathrm{~m}$ ) to the Russian coast (thickness around $100 \mathrm{~m})$. The seasonal thermocline occurs from the surface to depth $50 \mathrm{~m}$ in May $\left(\sim 0.08^{\circ} \mathrm{C} \mathrm{m}^{-1}\right)$, intensifies during the summer monsoon season to a maximum value of around $0.5^{\circ} \mathrm{C} \mathrm{m}^{-1}$ in August and September, and weakens in October. In November, the seasonal thermocline erodes and becomes the part of the permanent thermocline, which weakens during the prevailing winter monsoon season.

3) Three important features are found from the monthly sea surface salinity anomaly field: a basinwide positive (negative) anomaly occurs in winter (summer); the seasonal variability of the surface salinity field is stronger south than north of the SPF; and there are two saline activity centers located at Tartar Strait and Tsushima Strait, respectively.

4) The seasonal haline variability has a strong northsouth asymmetry with an evident salinity minimum south of the SPF and absence of a salinity minimum north of the SPF. South of the SPF, the SMIN $(S<$ $34.06 \mathrm{psu}$ ) occurs during the summer monsoon season (Jul-Oct) underneath a horizontally oriented SMAX with a salty core $(S>34.5 \mathrm{psu})$ at depth $100 \mathrm{~m}$. The interface between the SMIN and the SMAX is located at depth 200-300 m. During the winter monsoon season, the SMIN becomes less evident. North of the SPF, the high, salinity water $(S>34.1 \mathrm{psu})$ of the HSIW appears in the central $\mathrm{JB}\left(40^{\circ}-43^{\circ} \mathrm{N}\right)$, strengthening in winter and weakening in summer.

5) The inverted absolute geostrophic velocities represent the JES circulation reasonably well, especially the Tsushima Current and its bifurcation. The Tsushima Current bifurcates into a western and an eastern branch north of the Korea/Tsushima Strait. The maximum speed of the western branch is found around $0.2 \mathrm{~m} \mathrm{~s}^{-1}$, occurring near the SPF at the surface. The maximum speed of the eastern branch is found around $0.1 \mathrm{~m} \mathrm{~s}^{-1}$, occurring near the Japanese coast $\left(135^{\circ} \mathrm{E}, 35.5^{\circ} \mathrm{N}\right)$ at the surface. The strength of the Tsushima Current in both branches reduces with depth. An evident cyclonic gyre is found in the mid-JES $\left(38^{\circ}-44^{\circ} \mathrm{N}, 135^{\circ}-140^{\circ} \mathrm{E}\right)$ with the flow associated with the SPF at its eastern flank and the flow from the north (mid-JES cold current) at its western flank.

6) The SPF current has a weak seasonal variation in flow pattern, a strong seasonal variation in current speed, and out-of-phase variability with the Tsushima Warm Current. When the SPF current strengthens from July $\left(0.18 \mathrm{~m} \mathrm{~s}^{-1}\right)$ to September $\left(0.22 \mathrm{~m} \mathrm{~s}^{-1}\right)$, the Tsushima Warm Current weakens from $0.12 \mathrm{~m} \mathrm{~s}^{-1}$ to $0.04 \mathrm{~m}$ $\mathrm{s}^{-1}$. When the SPF current weakens from January $(0.18$ $\left.\mathrm{m} \mathrm{s}^{-1}\right)$ to April $\left(0.12 \mathrm{~m} \mathrm{~s}^{-1}\right)$, the Tsushima Warm Current strengthens from $0.02 \mathrm{~m} \mathrm{~s}^{-1}$ to $0.1 \mathrm{~m} \mathrm{~s}^{-1}$. The seasonal variability of the mid-JES cyclonic gyre is largely determined by the seasonal variability of the SPF current. The volume transport of the SPF current has a maximum value of $1.32 \mathrm{~Sv}$ in November-December and a minimum value of $0.88 \mathrm{~Sv}$ in April.

Acknowledgments. This work was funded by the Office of Naval Research NOMP Program, the Naval Oceanographic Office, and the Naval Postgraduate School.

\section{REFERENCES}

Chu, P. C., 1995: P-vector method for determining absolute velocity from hydrographic data. Mar. Tech. Soc. J., 29, 3-14.

_ 2000: P-vector spirals and determination of absolute velocities. J. Oceanogr., 56, 591-599.

—, and R. F. Li, 2000: South China Sea isopycnal-surface circulation. J. Phys. Oceanogr., 30, 2419-2438.

— , H.-C. Tseng, C. P. Chang, and J. M. Chen, 1997a: South China Sea warm pool detected in spring from the Navy's master oceanographic observational data set (MOODS). J. Geophys. Res., 102, 15 761-15 771 .

, S. H. Lu, and Y. C. Chen, 1997b: Temporal and spatial variabilities of the South China Sea surface temperature anomaly. J. Geophys. Res., 102, 20 937-20955.

—, S. K. Wells, S. D. Haeger, C. Szczechowski, and M. Carron, 1997c: Temporal and spatial scales of the Yellow Sea thermal variability. J. Geophys. Res., 102, 5655-5668.

, C. R. Fralick, S. D. Haeger, and M. J. Carron, 1997d: A para- 
metric model for Yellow Sea thermal variability. J. Geophys. Res., 102, $10499-10508$.

_ , Y. C. Chen, and S. H. Lu, 1998a: Temporal and spatial variabilities of Japan Sea surface temperature and atmospheric forcing. J. Oceanogr., 54, 273-284.

— C. W. Fan, and W. J. Cai, 1998b: Evaluation of P-vector method using modular ocean model (MOM). J. Oceanogr., 54, 185-198.

- C. C. J. Lozano, and J. L. Kerling, 1998c: An airborne expandable bathythermograph survey of the South China Sea, May 1995. J. Geophys. Res., 103, 21 637-21 652.

Hase, H., J.-H. Yoon, and W. Koterayama, 1999: The current structure of the Tsushima Warm Current along the Japanese coast. $J$. Oceanogr., 55, 217-235.

Hong, C. H., K. D. Cho, and S. K. Yang, 1984: On the abnormal cooling phenomenon in the coastal areas of East Sea of Korea in summer 1981. J. Oceanol. Soc. Korea, 19, 11-17.

Isoda, Y., and S. Saitoh, 1988: Variability of the sea surface temperature obtained by the statistical analysis of AVHRR imagery-A case study of the south Japan Sea. J. Oceanogr. Soc. Japan, 44, 52-59.

—, and — 1993: The northward intruding eddy along the east coast of Korea. J. Oceanogr., 49, 443-458.

Kajiura, K., M. Tsuchiya, and K. Hidaka, 1958: The analysis of oceanographical condition in the Japan Sea (in Japanese). Rep. Dev Fish. Resour. Tsushima Warm Current, 1, 158-170.

Kano, Y., 1980: The annual variation of the temperature, salinity and oxygen contents in the Japan Sea. Oceanogr. Mag., 31, 15-26.

Kawabe, M., 1982a: Branching of the Tsushima Current in the Japan Sea. Part I: Data analysis. J. Oceanogr. Soc., 38, 95-107. , 1982b: Branching of the Tsushima Current in the Japan Sea. Part II: Numerical experiment. J. Oceanogr. Soc., 38, 183-192.

Kim, C.-H., and J.-H. Yoon, 1996: Modeling of the wind-driven circulation in the Japan Sea using a reduced gravity model. $J$. Oceanogr., 52, 359-373.

Kim, K., and J. Y. Chung, 1984: On the salinity-minimum and dissolved oxygen-maximum layer in the East Sea (Sea of Japan). Ocean Hydrodynamics of the Japan and East China Seas, T. Ichiye, Ed., Elsevier Science, 55-65.

— , Y.-G. Kim, Y.-K. Cho, M. Takematsu, and Y. Volkov, 1999 Basin-to-basin and year-to-year variation of temperature and salinity characteristics in the East Sea (Sea of Japan). J. Oceanogr. 55, 103-109.

Kim, Y.-G., and K. Kim, 1999: Intermediate waters in the East/Japan Sea. J. Oceanogr., 55, 123-132.

Maizuru Marine Observatory, 1997: Climate chart of the Japan Sea. Maizuru, Japan.

Miyazaki, M., 1952: The heat budget of the Japan Sea (in Japanese with English abstract). Bull. Hokkaido Reg. Fish. Res. Lab., 4, $1-54$.
1953: On the water masses of the Japan Sea (in Japanese with English abstract). Bull. Hokkaido Reg. Fisher. Res. Lab., 7, 1-65.

- and S. Abe, 1960: On the water masses in the Tsushima Current area (in Japanese with English abstract). J. Oceanogr. Soc. Japan, 16, 19-28.

Moriyasu, S., 1972: The Tsushima current. Kuroshio, Its Physical Aspects, H. M. Stommel and K. Yoshida, Eds., University of Tokyo Press, 353-369.

Sekine, Y., 1986: Wind-driven circulation in the Japan Sea and its influence on the branching of the Tsushima Current. Progress in Oceanography, Vol. 17, Pergamon, 297-312.

Senjyu, T., 1999: The Japan Sea Intermediate Water: Its characteristics and circulation. J. Oceanogr., 55, 111-122.

Seung, Y.-H., 1994: The separation of the East Korean Warm Current and the mechanism for the formation of the North Korean Cold Current (in Japanese). Kaiyo Mon., 758-765.

— the Japan Sea. J. Oceanogr., 51, 61-73.

Suda, K., and K. Hidaka, 1932: The results of the oceanographic observations on board R.M.S. 'Sуипри Maru' in the southern part of the Japan Sea in the summer of 1930 (in Japanese). $J$. Oceanogr. Imp. Mar. Observ., 4, 1-174.

,-- , Y. Matsudaira, E. Kurashige, H. Kawasaki, and T. Kubo, 1932: The results of the oceanographic observations on board R.M.S. 'Sуипри Maru' in the southern part of the Japan Sea in the summer of 1929. Part 1 (in Japanese). J. Oceanogr. Imp. Mar. Observ., 3, 291-375.

Suk, M.-S., 1988: Application of a variational inverse model to determine a wintertime circulation in the East Sea of Korea. Progress in Oceanography, Vol. 21, Pergamon, 281-293.

Teague, W. J., M. J. Carron, and P. J. Hogan, 1990: A comparison between the Generalized Digital Environmental Model and Levitus climatologies. J. Geophys. Res., 95, 7167-7183.

Tomczak, M., and J. S. Godfrey, 1994: Regional Oceanography: An Introduction. Pergamon, $422 \mathrm{pp}$.

Uda, M., 1934: The results of simultaneous oceanographic investigations in the Japan Sea and its adjacent waters in May and June, 1932 (in Japanese). J. Imp. Fish. Exp. Sta., 5, 57-190.

Wunsch, C., and B. Grant, 1982: Towards the general circulation of the North Atlantic Ocean. Progress in Oceanography, Vol. 11, Pergamon, 1-59.

Yoon, J.-H., 1982a: Numerical experiment on the circulation in the Japan Sea. Part I: Formation of the East Korean Warm Current. J. Oceanogr. Soc. Japan, 38, 43-51.

- 1982b: Numerical experiment on the circulation in the Japan Sea. Part II: Influence of seasonal variations in atmospheric conditions on the Tsushima Current. J. Oceanogr. Soc. Japan, 38, $81-94$.

1982c: Numerical experiment on the circulation in the Japan Sea. Part III: Mechanism of the nearshore branch of the Tsushima Current. J. Oceanogr. Soc. Japan, 38, 125-130. 